\title{
ENTRE A ESCRAVIDÃO E A LIBERDADE: \\ AS ALFORRIAS EM MARIANA-MG \\ NO SÉCULO XIX (1840-1888)
}

Heloísa Maria Teixeira*

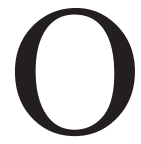

presente trabalho analisa a prática das alforrias na localidade mineira de Mariana. A partir da análise de 425 cartas de liberdade registradas nos cartórios dos I e II ofícios do termo de Mariana, descrevem-se os padrões da alforria do período 1840-1888, buscando apreender as transformações na concessão da manumissão no contexto das leis abolicionistas. O marco inicial estabelecido justifica-se por ser a década que antecede a proibição efetiva do tráfico internacional de escravos. A análise das alforrias para os anos 1840 permite estabelecer uma comparação com as décadas subsequentes e, assim, dimensionar o impacto causado pelas leis abolicionistas na política de alforrias.

Em 1850, a lei que proibiu o tráfico africano inaugurou o declínio do sistema escravista brasileiro. A partir de então, houve constante diminuição do número de cativos no país, o que resultou em grande movimentação interna em busca da mão de obra escrava residente no país, mormente das regiões menos mercantilizadas para aquelas voltadas para o mercado externo. Outra forma de aumentar o número de cativos seria a reprodução endógena. No entanto, em 21 de setembro de 1871, a legislação causou ainda mais embaraço ao sistema escravista. A partir

\footnotetext{
* Pós-doutoranda em História Econômica da FEA/USP.
} 
daquela data, crianças que nascessem de ventre escravo seriam declaradas livres. A mesma lei permitiu ao cativo a acumulação de pecúlio para ser usado na compra da própria alforria e ainda instituiu um fundo que tinha como propósito a emancipação. O Estado passou, assim, a mediar a relação senhor/escravos, ampliando-se, desse modo, a esperança da conquista da liberdade. A intervenção do Estado na relação senhor/escravo foi reforçada pela lei de 1885, conhecida como Lei dos Sexagenários ou Lei Saraiva-Cotegipe, que, além de libertar os escravos com mais de 65 anos, fixava o valor máximo que os escravos poderiam atingir nas negociações de vendas ou emancipações.

A localidade de Mariana encontrava-se, durante o período 18401888, envolta em intensa diversificação de atividades econômicas, com predominância daquelas ligadas às atividades agrícolas e pastoris, mas também havia propriedades ocupadas com a mineração e a siderurgia. Observando-se os inventários post-mortem, constata-se que, entre os gêneros cultivados, destacavam-se a produção de gêneros de primeira necessidade - milho, arroz, feijão, açúcar, etc. — e o café. Nas atividades pastoris, predominava a criação de suínos, seguida pela de bovinos e equinos. Era comum a conjugação de várias culturas e a criação de animais nas propriedades marianenses. ${ }^{1}$

\section{Alforrias em Mariana-MG (1840-1888)}

A carta de alforria era um documento no qual o proprietário do escravo identificava-se e, em seguida, descrevia informações sobre o alforriado. Em geral, fornecia nome, idade, cor, estado civil, filiação, além das condições da alforria. Em algumas ocasiões, trazia também a ocupação do cativo.

Boa parte dessas cartas era registrada em cartórios, oficializando a liberdade do escravo. Esse recurso protegia não só o liberto, mas também o senhor: para o primeiro, o registro evitava possíveis contestações quanto à vontade do proprietário, principalmente por parte dos herdeiros, além de evitar a escravização de libertos; para o segundo, o registro

Heloísa Maria Teixeira, "Reprodução e famílias escravas em Mariana - 1850-1888” (Dissertação de Mestrado, Universidade de São Paulo, 2001). 


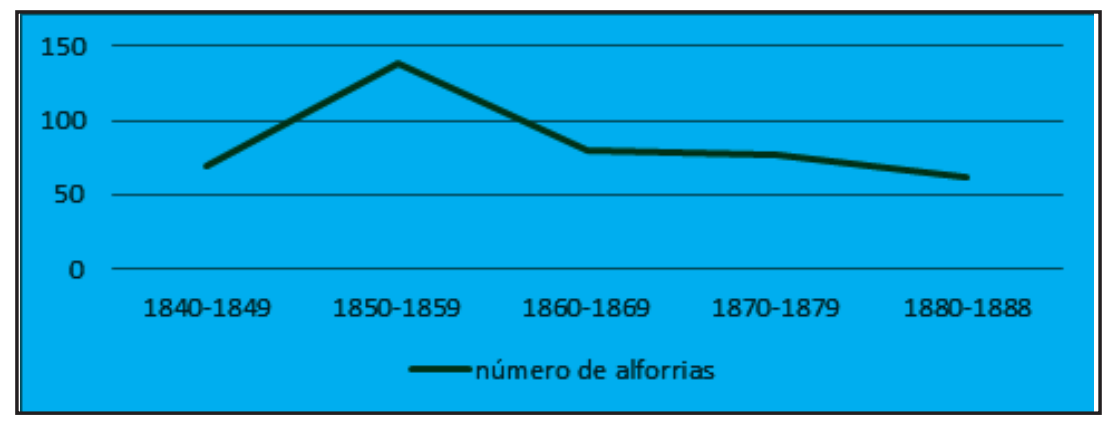

Gráfico 1 - Cartas de alforrias registradas em cartórios (Mariana - 1840-1888)

Fonte: Cartas de alforria. Arquivo da Casa Setecentista de Mariana.

resguardava os termos acertados com o escravo, facilitando a cobrança do cumprimento das condições impostas.

Por suas características, as cartas de liberdade constituem-se em fontes privilegiadas pelo fato de possibilitar um estudo quantitativo das variáveis associadas ao estudo das manumissões e por fornecer informações que permitem reconstituir os principais mecanismos que presidiam a política de alforrias, ensejando a análise de seu ritmo durante a segunda metade do século XIX. O Gráfico 1 apresenta a concessão das alforrias no período 1840-1888, registradas em cartórios de Mariana.

A curva do Gráfico 1 revela acentuada queda do número de registros de alforria entre as décadas de 1850 e $1860 .^{2}$ Nas décadas seguintes, a tendência é a mesma, porém, de forma menos pronunciada. Pode-se associar o movimento do Gráfico 1 à lei que proibia a entrada de escravos africanos nos portos brasileiros. Conforme revela a historiografia, a Lei Eusébio de Queiroz resultou em quase imediata elevação de preços dos cativos - o que tornou a compra da liberdade ainda mais difícil para aqueles que vinham economizando com essa intenção - e em intenso tráfico interno que deslocou escravos das regiões menos mercantilizadas para aquelas envolvidas com a economia de exportação, reduzindo, em

Para a década de 1840, apenas um livro de notas com registros de cartas de alforria foi localizado para o I Ofício e nenhum para o II. Desse modo, são em menor número esses registros de alforria em relação às décadas posteriores. 
associação direta, o número de alforrias nas áreas de economia voltada para o mercado interno. Percebe-se uma diminuição dos inventários postmortem contendo escravos em Mariana entre 1840 e 1888 (Tabela 1).

Tabela 1 - Inventários post-mortem que mencionam escravos (Mariana-MG - 1840-1888)

\begin{tabular}{ccc}
\hline Décadas & $\begin{array}{c}\text { Número } \\
\text { de inventários }\end{array}$ & $\begin{array}{c}\text { Número } \\
\text { de escravos }\end{array}$ \\
\hline $1840-1849$ & 138 & 1471 \\
$1850-1859$ & 136 & 1195 \\
$1860-1869$ & 111 & 1143 \\
$1870-1879$ & 108 & 1101 \\
$1880-1888$ & 38 & 356 \\
Total & 531 & 5266 \\
\hline
\end{tabular}

Fonte: Inventários post-mortem. Arquivo da Casa Setecentista de Mariana.

Comparadas as décadas de 1840 e 1850, decresce de forma significativa o número de escravos arrolados nos inventários, porém essa redução torna-se menos acentuada estando em cotejo as décadas seguintes. Nos últimos anos da escravidão, o número de inventários que continham escravos sofre uma queda abrupta e, por consequência, o número de escravos cai vertiginosamente.

Antes do fim do tráfico internacional, Mariana parece ter recorrido com surpreendente frequência à compra de africanos. Boa parte da população cativa $(28,6 \%)$ descrita nos inventários dos anos 1840 era formada por homens oriundos de ultramar. Essa intensa participação se reduz significativamente nos anos seguintes: $15,0 \%$ na década de $1850 ; 14,6 \%$ nos anos $1860 ; 6,4 \%$ nos 1870 ; e 5,1\% nos 1880 . A redução do número de inventários que continham escravos ao longo das décadas sugere que a mão de obra mancípia estava em queda nas propriedades marianenses. Parte desse declínio decorreria, provavelmente, da transferência de escravos para outras localidades, embora também devam ser ressaltados os efeitos das leis de 1871 e 1885.

A diminuição do contingente cativo após 1850, seja por efervescência do tráfico interno, seja por inoperância do tráfico internacional 
nos portos do país, é o mais óbvio motivo do decréscimo das alforrias ao longo da segunda metade do século XIX em Mariana; contudo, deve ser lembrado que a concessão da liberdade tornou-se mais custosa em consequência da maior dificuldade na reposição da mão de obra. As ações de liberdade abertas em Mariana, nas últimas décadas do século XIX, além de refletirem o sentimento abolicionista, traduziam também a resistência dos proprietários marianenses em se desfazer de sua mão de obra. A maioria dessas ações arrastou-se no tempo, tornando-se volumosos processos, em decorrência da luta acirrada entre escravos que se consideravam viver em injusto cativeiro e escravistas que buscavam manter a propriedade. ${ }^{3}$

A mesma situação foi percebida em regiões de mais diferentes configurações econômicas, mas não exportadoras. Analisando as alforrias para a cidade de São Paulo durante o século XIX, Enidelce Bertin também encontrou diminuição do número de registros das cartas de liberdade após o ano de $1850,{ }^{4}$ queda essa, segundo ela, atrelada ao encolhimento do contingente escravo na cidade de São Paulo.

A extinção do tráfico africano em 1850 e a consequente busca por escravos no mercado interno contribuíram para alterar de alguma forma a presença escrava na cidade. Primeiramente porque as vendas de escravos para os fazendeiros tornaram-se uma oportunidade de negócio para os

Heloísa Maria Teixeira, "Livres, porém escravos: o injusto cativeiro e a luta de uma família negra pela liberdade (Mariana, século XIX)", Anais do XVI Encontro Regional de História, Belo Horizonte: ANPUH-MG, 2008; Heloísa Maria Teixeira, "Injusto cativeiro: a luta dos africanos pela liberdade (Mariana, segunda metade do século XIX)", Anais do XVIII Encontro Regional de História, Belo Horizonte: ANPUH-MG, 2012.

4 Enidelce Bertin, Alforrias na São Paulo do século XIX: liberdade e dominação, São Paulo: Humanitas, 2004. Bertin estudou as cartas de alforria na cidade de São Paulo do período 18001888, analisando, no total, 1.105 cartas correspondentes a 1.338 escravos. Objetivando melhor compreensão das alforrias no contexto político da escravidão nos Oitocentos, a autora, baseando-se na legislação abolicionista, considerou três recortes cronológicos: 1800-1849, 1850-1870, 18711888. Das 1.105 cartas analisadas, 917 foram registradas no período $1800-1849 ; 221$ no período 1850-1870 e 162 no período 1871-1888. Segundo a autora, "a maior incidência de cartas de liberdade na primeira metade do século indica a força da prática costumeira de alforriar, mesmo antes das pressões legais ou da campanha abolicionista. A queda nas alforrias na segunda metade do século teria sido efeito da crise na oferta de mão de obra a partir da lei de 4 de setembro de 1850 . [...] O pequeno número de registros de cartas que se verifica na última década sugere a gradual rarefação no número de escravos na cidade - em parte, produto da transferência de escravos para o interior no momento de falta de mão de obra nas lavouras cafeeiras" (Bertin, Alforrias na São Paulo, pp.69-70). 
proprietários urbanos que quisessem se desfazer de algum cativo — o que teria sido um dos fatores de diminuição da população escrava na cidade. ${ }^{5}$

Andrea Lisly Gonçalves, estudando as alforrias do período 18081870 na comarca de Ouro Preto-MG - região que esteve no centro das atividades mineradoras do século XVIII e que, no século XIX, embora ainda mantivesse exploração mineradora considerável, ganhava força com a produção e o comércio de gêneros alimentícios —, também observou diminuição do número de cartas a partir da década de 1830, que se tornou mais acentuada a partir de 1850. Para a autora, a redução do número de registros estava atrelada à cessão do tráfico internacional de escravos — iniciada em 1830 e definida em 1850 - e consequente aumento do preço do escravo. ${ }^{6}$

Em contrapartida, nas regiões economicamente mais dinâmicas, o movimento das alforrias durante a segunda metade do século XIX é inverso. Lizandra Meyer Ferraz, com base em extensa documentação testamentos, inventários post-mortem e cartas de liberdade -, analisou as alforrias em Campinas-SP em dois períodos (1836-1845 e 1860-1871) e constatou que, após a proibição da entrada de africanos escravizados, houve aumento das manumissões, sobretudo para as grandes escravarias. Para Ferraz,

[...] o aumento nesta frequência deve estar ligado à adoção de uma política senhorial de controle tanto da população cativa (através da expectativa de liberdade) quanto da população liberta (através do recurso da gratidão) numa época em que os primeiros sinais do fim da escravidão já estavam sendo soados. ${ }^{7}$

A investigação realizada por Hebe Maria Mattos para as fazendas cafeeiras do Sudeste brasileiro revela que, no período posterior a 1850, quando a mão de obra escrava começou a escassear, não foi verificada diminuição das alforrias, interpretada por ela como resultado da maior pressão dos escravos e da crise na autoridade senhorial. A seu ver, no

Bertin, Alforrias na São Paulo, p.49.

Andréa Lisly Gonçalves, As margens da liberdade: estudo sobre a prática de alforrias em Minas colonial e provincial, Belo Horizonte: Fino Traço, 2011.

7 Lizandra Meyer Ferraz, "Testamentos, alforrias e liberdade: Campinas, século XIX” (Monografia de Bacharelado em História, Universidade Estadual de Campinas, 2006), p.87. 
final da escravidão, a autoridade moral dos senhores estava em risco, motivo pelo qual as alforrias funcionariam como estratégia para evitar a interferência do poder público e preservar laços de sujeição e dependência com seus ex-escravos. ${ }^{8}$

Antônio Henrique Duarte Lacerda analisou os padrões de alforria para a região cafeeira de Juiz de Fora-MG do período $1844-1888$ a partir de 744 cartas de liberdade: desse total, 56,71\% foram concedidas no período 1844-1880, e 43,29\%, nos últimos anos do período escravista, ou seja, entre 1881 e $1888 .{ }^{9}$ Os dados de Lacerda aproximam-se dos estudos historiográficos que apontam a década de 1880 como o período em que ocorreram mais alforrias, muitas delas coletivas.

\section{O padrão das manumissões em Mariana-MG no período $1840-1888$}

Buscando identificar os padrões das manumissões dentro das transformações surgidas na conjuntura das leis abolicionistas, as alforrias concedidas em Mariana foram agrupadas em (i) condicionais - aquelas cujos escravos alcançariam a liberdade mediante alguma condição, principalmente pagamento em dinheiro ou prestação de serviços; (ii) incondicionais - sem nenhuma condição explícita; e (iii) fornecidas pelo Estado, atendendo à legislação abolicionista. ${ }^{10}$

Confirmando os estudos historiográficos, constata-se a predominância das alforrias condicionais. Somando-se aquelas que foram concedidas mediante pagamento em dinheiro e prestação de serviços chega-se

Hebe Maria Mattos, Das cores do silêncio: os significados da liberdade no sudeste escravista - Brasil, século XIX, Rio de Janeiro: Nova Fronteira, 1999.

9 Antônio Henrique Lacerda, Os padrões das alforrias em um município cafeeiro em expansão: Juiz de Fora, zona da mata de Minas Gerais, 1844-1888, São Paulo: Annablume, 2006, p.63.

10 Peter Eisenberg classificou as cartas de alforria concedidas em Campinas, no século XIX, como gratuitas e onerosas. Segundo ele, "a carta de alforria podia ser elaborada sem condição alguma, uma liberdade incondicional que o jurista chamava de um contrato a título gratuito. Alternativamente, a carta podia ser elaborada com condições restritivas, uma liberdade condicionada, com contrapartida pelos dois lados, e que era considerado um contrato a título oneroso" (Peter L. Eisenberg, "Ficando livre: as alforrias em Campinas no século XIX", Estudos Econômicos, v.17, n.2 (1987), p.196, grifos do autor). Sua classificação foi adotada no presente estudo, porém, para melhor compreensão dos efeitos das leis abolicionistas, foi necessário distinguir as alforrias forçadas pela interferência do Estado. 


\begin{tabular}{ccccccc}
\hline & Condicional & & $\begin{array}{c}\text { Incondicional } \\
\text {-sem ônus }\end{array}$ & $\begin{array}{c}\text { Estado/Leis } \\
\text { abolicionistas }\end{array}$ & Total \\
$\begin{array}{c}\text { Prestação } \\
\text { de serviços }\end{array}$ & $\begin{array}{c}\text { Pagamento } \\
\text { em dinheiro }\end{array}$ & Outros & & & \\
\hline 259 & 108 & 1 & 169 & 28 & $565^{*}$ \\
$45,8 \%$ & $19,1 \%$ & $0,2 \%$ & $29,9 \%$ & $5,0 \%$ & $100 \%$ \\
& 368 & & & & \\
\hline $65,1 \%$ & & & & & \\
\hline
\end{tabular}

*Não se conseguiu saber a condição de quatro escravos, pelo fato de o documento encontrar-se danificado. Fonte: Cartas de alforria. Arquivo da Casa Setecentista de Mariana.

à porcentagem de $65,1 \%$, mais que o dobro das alforrias incondicionais. Em menor escala, registram-se as manumissões concedidas pelo Estado com base na lei que, a partir de 1871, vigorou no país. Por meio da Lei Rio Branco - que, além de libertar as crianças que nascessem de ventre escravo, instituiu um fundo financeiro que tinha como propósito a emancipação de escravos e ainda permitiu ao cativo a acumulação de pecúlio para ser usado na compra da própria alforria —, o Estado passou a mediar as relações entre escravos e senhores, retirando destes últimos o controle da esperança da alforria junto a seus cativos.

Distribuindo-se as alforrias segundo as décadas, de maneira geral, as condicionais diminuíram ao longo do período, ao passo que as incondicionais cresceram em importância. ${ }^{11}$ Mesmo com essa observação, em todas as décadas, a porcentagem de cartas que exigiam alguma contrapartida foi

11 Andréa Lisly Gonçalves, analisando 1.874 cartas de liberdade registradas na Comarca de Ouro Preto - sede administrativa e eclesiástica da província e concentradora da maior porcentagem de escravos e população livre das Minas - , no período 1808-1870, constatou predominância das manumissões condicionais $(70,29 \%$ do total). Entretanto, observou tendência à diminuição do número de alforrias ao longo do tempo, sendo mais marcante a queda das alforrias condicionais (Gonçalves, As margens da liberdade, p.211). Buscando compreender o movimento das alforrias, baseando-se em critérios relacionados com o movimento do tráfico, a autora dividiu o período de análise em três subperíodos - 1808-1831, 1832-1850 e 1851-1870 —, com as seguintes médias constatadas: no subperíodo 1808-1831,35,63\% foram alforrias condicionais e 17,27\%, incondicionais; no subperíodo subsequente, as condicionais foram $15,63 \%$ e as incondicionais, $6,03 \%$; no último subperíodo, $9,91 \%$ foram de alforrias condicionais, e 4,25\% de incondicionais (Gonçalves, As margens da liberdade, p.214). Para Gonçalves, a questão do tráfico internacional de escravos e o consequente aumento do preço do escravo apresentaram-se como principais explicações para a queda do número de alforrias. 
Tabela 3 - Tipos de alforria segundo as décadas

(Mariana-MG - 1840-1888)

\begin{tabular}{|c|c|c|c|c|c|c|}
\hline \multirow[t]{2}{*}{ Décadas } & \multicolumn{3}{|c|}{ Condicional } & \multirow{2}{*}{$\begin{array}{c}\text { Incondicional } \\
\text { - sem ônus }\end{array}$} & \multirow{2}{*}{$\begin{array}{l}\text { Estado /Leis } \\
\text { abolicionistas }\end{array}$} & \multirow[t]{2}{*}{ Total } \\
\hline & $\begin{array}{l}\text { Prestação } \\
\text { de } \\
\text { serviços }\end{array}$ & $\begin{array}{l}\text { Pagamento } \\
\text { em dinheiro }\end{array}$ & Outros & & & \\
\hline \multirow{3}{*}{$1840-1849$} & 73 & 19 & - & 15 & - & $107^{*}$ \\
\hline & $68,2 \%$ & $17,8 \%$ & & $14,0 \%$ & & \\
\hline & \multicolumn{2}{|c|}{$\begin{array}{c}92 \\
86,0 \%\end{array}$} & & & & \\
\hline \multirow{3}{*}{ 1860-1869 } & 80 & 38 & & & & \\
\hline & $45,4 \%$ & $21,6 \%$ & - & 58 & - & $176^{* *}$ \\
\hline & \multicolumn{2}{|c|}{$\begin{array}{c}118 \\
67,0 \%\end{array}$} & & $33,0 \%$ & & \\
\hline \multirow{3}{*}{$1860-1869$} & 53 & 19 & & & & \\
\hline & $51,0 \%$ & $18,2 \%$ & 1 & 30 & 1 & $104 * * *$ \\
\hline & \multicolumn{2}{|c|}{$\begin{array}{c}72 \\
69,2 \%\end{array}$} & $1,0 \%$ & $28,8 \%$ & $1,0 \%$ & \\
\hline \multirow{3}{*}{$1870-1879$} & 33 & 21 & - & 35 & 12 & 101 \\
\hline & $32,7 \%$ & $20,8 \%$ & & $34,6 \%$ & $11,9 \%$ & \\
\hline & \multicolumn{2}{|c|}{$\begin{array}{c}54 \\
53,5 \%\end{array}$} & & & & \\
\hline \multirow{3}{*}{$1880-1888$} & 20 & 11 & - & 31 & 15 & 77 \\
\hline & $26,0 \%$ & $14,3 \%$ & & $40,3 \%$ & $19,4 \%$ & \\
\hline & \multicolumn{2}{|c|}{$\begin{array}{c}31 \\
40,3 \%\end{array}$} & & & & \\
\hline
\end{tabular}

Notas: *Para uma escrava, não foi atestado o tipo de alforria concedido; ** para um escravo, não foi atestado o tipo de alforria concedido; ${ }^{* * *}$ para um escravo e uma escrava, não foi atestado o tipo de alforria concedido.

Fonte: Cartas de alforria. Arquivo da Casa Setecentista de Mariana. 


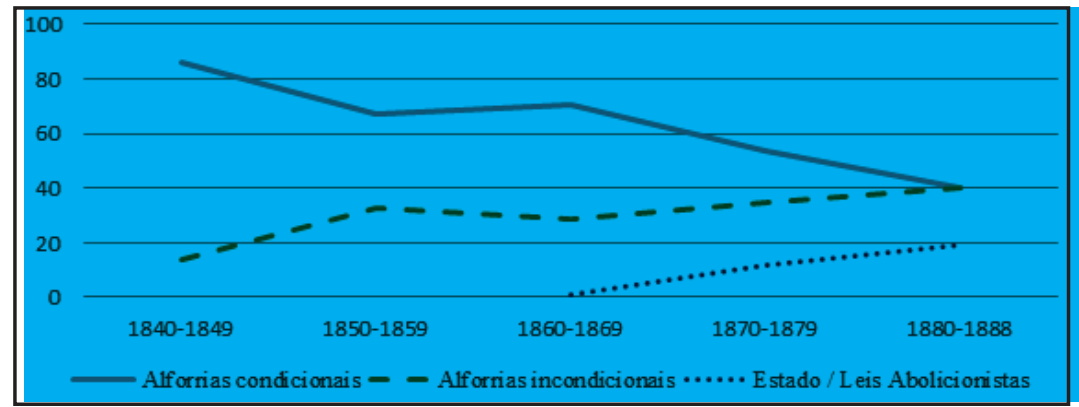

Gráfico 2 - Tipos de alforria por décadas (Mariana-MG - 1840-1888)

Fonte: Cartas de alforria. Arquivo da Casa Setecentista de Mariana.

superior à das incondicionais, exceção para os anos 1880, quando alforrias condicionais e incondicionais foram concedidas na mesma proporção. Se, na década de $1840,86 \%$ das manumissões registradas foram condicionais, e $14 \%$, incondicionais, nos anos 1880-1888, cada um dos tipos tinha exatamente a mesma representatividade $(40,3 \%)$ entre as cartas registradas, como mostra o Gráfico 2.

O movimento das alforrias observado na Tabela 3 e no Gráfico 2 deve ser explicado de acordo com a conjuntura da época. Apesar da tentativa de proibição de entrada de escravos africanos no Brasil em 1830, foi somente a partir de 1850 que a interdição aconteceu de fato, modificandose toda a estrutura da escravidão no país. Um cotejo entre as décadas de 1840 e 1850 aponta uma brusca transformação no padrão das alforrias. Enquanto, na primeira década, $86 \%$ das alforrias foram concedidas sob alguma condição, na década seguinte, as mesmas decaíram para $67 \%$. Já o movimento das libertações incondicionais demonstrou-se contrário, aumentando, de uma década para outra, de $14 \%$ para $33 \%$. Nos anos 1860 , o paradigma permanece próximo ao estabelecido na década anterior: as condicionais tornam-se $70,2 \%$, e as incondicionais, $28,8 \%$ do total das alforrias registradas. Para as últimas décadas da escravidão, o percentual de alforrias condicionais tem declínio mais significativo, sobretudo nos anos 1880 , quando chegam a $40,3 \%$ do total de manumissões e atingem taxa idêntica à das concedidas incondicionalmente. As Tabelas 2 e 3 e o Gráfico 2 mostram ainda as alforrias concedidas por intermédio do Estado, que surgem como consequência da lei de 1871. Antes dessa data, 
tem-se notícia de apenas um caso de alforria concedida pelo Estado: no ano de 1866, o escravo Bernardino, de 35 anos, muito doente, requereu e conseguiu sua emancipação por intermédio da Justiça, justificando que possuía o valor correspondente ao de sua carta. ${ }^{12}$

Os dados de Mariana aproximam-se dos encontrados por Bertin, que, investigando as cartas de alforria da cidade de São Paulo do século XIX, observou que as alforrias onerosas foram mais numerosas no decorrer de todo o Oitocentos: $72 \%$ do total das libertações. Distribuindo os tipos de alforrias por períodos $(1800-1850 ; 1850-1871 ; 1871-1888)$, a autora observa que "as onerosas (que envolveram pagamento e/ou condição) foram predominantes em todo o século, embora na última fase da escravidão tenha havido uma diminuição (respectivamente, 75,15\%; 72,41\%; 55,04\%)". ${ }^{13}$ Já as alforrias sem qualquer ônus foram aumentando ao longo desses três períodos $(24,9 \%, 27,48 \%, 44,94 \%$, respectivamente), o que "poderia ser explicado pelas dificuldades dos proprietários da cidade de São Paulo em manter seus escravos, considerando que o tráfico interno provocava um abastecimento deficitário para o Sudeste, o que resultou no encarecimento da mão de obra". ${ }^{14}$ Diante dessa conjuntura, segundo a autora, a emancipação sem ônus em plena época de carestia da mão de obra escrava poderia ser o último recurso dos proprietários para agregar os libertos com o recurso da gratidão devida.

A alforria assume, portanto, um caráter político, na medida em que é tomada como recurso de controle sobre os escravos libertos. Outra explicação possível para o crescimento das alforrias gratuitas e uma diminuição das onerosas em plena época de crise na mão de obra pode ser encontrada na apreensão dos proprietários em restringir a liberdade em momentos de intensa agitação escrava pelo interior, ou ainda como resultado da pressão dos abolicionistas. ${ }^{15}$

12 Carta de Alforria (31/10/1866), Arquivo da Casa Setecentista de Mariana (ACSM), I ofício, livro de notas número 118 (1864-1868), folhas 142-142v.

13 Bertin, Alforrias na São Paulo, p.83.

14 Bertin, Alforrias na São Paulo, p.84. “A composição de um quadro característico da escravidão em sua versão paulistana deve também considerar o cenário de recursos urbanos parcos, no qual, muitas vezes, a classe proprietária de escravos apresentava-se muito pobre. Apenas nas décadas finais do século, a economia cafeeira permitiu alterações significativas nesse quadro, especialmente devido à maior urbanização" (Bertin, Alforrias na São Paulo, p.37).

15 Bertin, Alforrias na São Paulo, pp.84-5. 
As cartas de alforria exaradas na localidade baiana de Rio de Contas durante o século XIX revelaram a Kátia Novais de Almeida a total predominância das alforrias pagas e condicionais, $73,7 \%$ do total, ao passo que as gratuitas foram $26,1 \%$. Quando analisadas por períodos, as proporções entre libertações condicionais e gratuitas mantiveram a mesma relação: para o período $1800-1850,71,8 \%$ das manumissões foram fornecidas sob alguma condição, e as gratuitas foram $27,9 \%$; para $1850-1871,79,2 \%$ foram condicionais, e as gratuitas, $20,8 \%$; para $1871-$ 1888 , as alforrias condicionais oscilaram para $72,5 \%$, e as incondicionais, para 27,4\%.$^{16}$ No período 1871-1888, as alforrias gratuitas cresceram 6,6 pontos percentuais em relação ao anterior. Esse crescimento

[...] pode sinalizar a adoção, por parte dos senhores, de uma estratégia para enfrentar a crise de mão de obra que se anunciava: por esta estratégia, criava-se a expectativa, para os que permaneciam escravos, de que trabalhar mais e melhor poderia resultar em uma carta de alforria gratuita. ${ }^{17}$

Para a autora, a alta porcentagem de alforrias condicionais seria "uma forma de os senhores sertanejos reterem e controlarem a mão de obra cativa”. Antes da lei de 1871, as condições impostas pelos senhores a seus escravos envolviam a prestação de serviços até a morte dos proprietários.

A análise das cartas de alforria em Juiz de Fora-MG para o período 1844-1888, realizada por Antônio Henrique Duarte Lacerda, também constatou que a maioria delas, $57,01 \%$, foi oferecida com alguma condição, e 42,99\%, incondicionalmente. ${ }^{18}$ Entretanto, agrupando as manumissões por tipo segundo as décadas, tem-se que: nos anos 1840, as condicionais eram $83,3 \%$ do total; na década seguinte, $52,1 \%$; nos anos $1860,42,8 \%$; nos anos $1870,48,4 \%$; e nos anos $1880,68,0 \%$. Quanto às alforrias gratuitas, elas representaram, respectivamente: $16,7 \%, 47,9 \%$, $57,2 \%, 51,6 \%$ e $32,0 \%$. Ficou constatado que, entre 1851 e 1880, as alforrias com alguma condição e aquelas incondicionais possuíram praticamente a mesma proporção, entretanto, na década final do escravismo,

16 Kátia Lorena Novais Almeida, "Da prática costumeira à alforria legal", Politéia, história e sociedade, v.1, n.1 (2007), p.167.

17 Almeida, "Da prática costumeira", p.180.

18 Lacerda, Os padrões das alforrias, p.63. 
as alforrias com alguma condição aumentaram significativamente. ${ }^{19}$ Para o autor, "este crescimento evidencia uma estratégia senhorial que visava o controle sobre a escravaria nos anos que antecederam a abolição, à medida que a população escrava aumentava face à expansão do café". ${ }^{20}$

Peter Eisenberg, examinando 2.093 papéis de liberdade que alforriaram 2.277 escravos em Campinas-SP, entre os anos de 1798 e 1888 - período de expansão da economia açucareira e cafeeira na região —, observa que as alforrias onerosas foram maioria para os três primeiros subperíodos analisados (1798-1850; 1851-1874 e 1875-1885), tendo ocorrido, porém, o contrário para os últimos anos da escravidão, com a concessão das alforrias gratuitas ultrapassando a das onerosas. $\mathrm{O}$ autor demonstra ainda que, embora maioria nos três primeiros subperíodos, as manumissões onerosas diminuíram sua participação ao longo do tempo, avultando-se as gratuitas. De acordo com os dados apresentados, as alforrias incondicionais eram $34,3 \%$ de todas as outorgadas no período $1798-1850 ; 35,0 \%$ no período $1851-1874 ; 46,2 \%$ em 1875-1885; e 61,9\% das concedidas no período 1886-1888. Quanto às alforrias onerosas, elas eram $65,7 \%$ das oferecidas no período $1798-1850 ; 65,0 \%$ no período $1851-1874 ; 53,8 \%$ em $1875-1885$ e $38,1 \%$ das concedidas entre os anos 1886 e $1888 .{ }^{21}$ Analisando o crescimento da alforria gratuita, Eisenberg aponta duas motivações: (i) as expectativas a respeito da sobrevivência da escravidão, sobretudo na década de 1880 , tornaram-se mais pessimistas haja vista a queda brusca dos preços dos escravos; (ii) o crescimento das revoltas escravas.

Foi nestes anos que a violência coletiva dos escravos, procurando a sua liberdade, chegou ao seu ponto máximo. Cobrar dinheiro ou uma prestação de serviços para a alforria tornou-se mais difícil, até pessoalmente perigoso, para um senhor de escravos. Nesta conjuntura, a gratuidade, amplamente divulgada na imprensa, aparecia como um investimento de boa vontade, e uma prova de que, apesar de sua associação com a instituição condenada, os senhores ainda mereciam o respeito da sociedade em geral, e dos libertos em particular. ${ }^{22}$

Lacerda, Os padrões das alforrias, p.65.

20 Lacerda, Os padrões das alforrias, p.35.

21 Eisenberg, "Ficando livre", p.197.

22 Eisenberg, "Ficando livre", p.211. 
Ponderando todos os casos aqui mencionados (Juiz de Fora, Campinas, São Paulo, Rio de Contas e Mariana) para o decorrer do século XIX, pode-se afirmar que a tendência geral foi de queda da predominância das alforrias condicionais. Todavia, são dignas de nota as idiossincrasias dissonantes de Rio de Contas, que, apesar das leves oscilações, manteve praticamente estáveis seus índices; e de Juiz de Fora, que contou com surpreendente aumento de concessões de alforrias condicionais a partir de 1870 .

De volta ao geral, dois aspectos são fundamentais para entender-se o movimento das manumissões: o perfil econômico da região estudada e os avanços das leis abolicionistas.

Nas áreas de economia pouco dinâmicas, como São Paulo e Mariana, o número total de alforrias caiu ao longo do tempo, provavelmente pela transferência de escravos — em particular após as leis de 1850 e 1871 — para regiões que tinham produção voltada para o mercado externo e necessitavam de maior concentração de mão de obra. Essas regiões de economia urbana, como São Paulo, e de produção de alimentos, como Mariana, ao perceberem seus contingentes cativos diminuírem continuamente, começaram a trabalhar em um cenário de manutenção de sua mão de obra a partir da libertação de seus escravos, recorrendo ao sentimento de gratidão, prática que se intensificou na década de 1880, quando as campanhas abolicionistas encorpavam-se com a adesão da sociedade, a inclinação do governo e a pressão internacional.

Em regiões de produção exportadora, como Juiz de Fora e Campinas, com seus cafezais carentes de mão de obra, a lógica é semelhante, apesar de uma distinção relevante: por aquelas plagas, crescia o contingente escravo - e, com ele, o número de alforrias. Na forma de libertar, entretanto, difere a cidade mineira da paulista: a partir de 1870, a primeira deu preferência às alforrias condicionais (que, embora maioria, decaíam desde 1840) e fê-las aumentar fortemente até 1888 , ao contrário da segunda, que chegou a alforriar a maioria dos contemplados com as cartas sem nada exigir. Cada região traçou sua estratégia de controle da força de trabalho nos anos finais da escravidão: os que optaram pela promessa da alforria sob alguma condição intencionavam adiar a liberdade para maior prazo de aproveitamento do elemento servil; e os que optaram pela libertação imediata criavam a tendência de manter a força de trabalho pela gratidão. 
Tabela 4 - Tipos de alforria segundo as décadas e o sexo do alforriado

(Mariana-MG - 1840-1888)

\begin{tabular}{|c|c|c|c|c|c|c|}
\hline \multirow{3}{*}{ Décadas } & \multicolumn{6}{|c|}{ Tipos de alforria } \\
\hline & \multicolumn{2}{|c|}{ Condicionais } & \multicolumn{2}{|c|}{ Gratuitas } & \multicolumn{2}{|c|}{ Fornecidas pelo Estado } \\
\hline & Homens & Mulheres & Homens & Mulheres & Homens & Mulheres \\
\hline 1840-1849* & $\begin{array}{c}44 \\
(7,8 \%)\end{array}$ & $\begin{array}{c}48 \\
(8,5 \%)\end{array}$ & $\begin{array}{c}5 \\
(0,9 \%)\end{array}$ & $\begin{array}{c}10 \\
(1,8 \%)\end{array}$ & - & - \\
\hline $1850-1859 * *$ & $\begin{array}{c}55 \\
(9,7 \%)\end{array}$ & $\begin{array}{c}63 \\
(11,2 \%)\end{array}$ & $\begin{array}{c}24 \\
(4,2 \%)\end{array}$ & $\begin{array}{c}34 \\
(6,0 \%)\end{array}$ & - & - \\
\hline $1860-1869 * * *$ & $\begin{array}{c}34 \\
(6,0 \%)\end{array}$ & $\begin{array}{c}39 \\
(6,9 \%)\end{array}$ & $\begin{array}{c}13 \\
(2,3 \%)\end{array}$ & $\begin{array}{c}16 \\
(2,8 \%)\end{array}$ & $\begin{array}{c}1 \\
(0,2 \%)\end{array}$ & - \\
\hline $1870-1879$ & $\begin{array}{c}27 \\
(4,8 \%)\end{array}$ & $\begin{array}{c}27 \\
(4,8 \%)\end{array}$ & $\begin{array}{c}17 \\
(3,0 \%)\end{array}$ & $\begin{array}{c}18 \\
(3,2 \%)\end{array}$ & $\begin{array}{c}7 \\
(1,25 \%)\end{array}$ & $\begin{array}{c}5 \\
(0,9 \%)\end{array}$ \\
\hline $1880-1888$ & $\begin{array}{c}15 \\
(2,7 \%)\end{array}$ & $\begin{array}{c}16 \\
(2,8 \%)\end{array}$ & $\begin{array}{c}13 \\
(2,3 \%)\end{array}$ & $\begin{array}{c}19 \\
(3,4 \%)\end{array}$ & $\begin{array}{c}7 \\
(1,25 \%)\end{array}$ & $\begin{array}{c}8 \\
(1,4 \%)\end{array}$ \\
\hline & $\begin{array}{c}175 \\
(31,0 \%)\end{array}$ & $\begin{array}{c}193 \\
(34,1 \%)\end{array}$ & $\begin{array}{c}72 \\
(12,7 \%)\end{array}$ & $\begin{array}{c}97 \\
(17,2 \%)\end{array}$ & $\begin{array}{c}15 \\
(2,7 \%)\end{array}$ & $\begin{array}{c}13 \\
(2,3 \%)\end{array}$ \\
\hline Total & & $\begin{array}{l}68 \\
1 \%)\end{array}$ & & $\begin{array}{l}69 \\
9 \%) \\
65 \\
0 \%)\end{array}$ & & \\
\hline
\end{tabular}

Notas: *Para uma escrava, não se conseguiu atestar o tipo de alforria concedido; ** para um escravo, não se conseguiu atestar o tipo de alforria concedido; ***para uma escrava e um escravo, não se consegwstar o tipo de alforria concedido.

Fonte: Cartas de alforria. Arquivo da Casa Setecentista de Mariana.

Embora a diferença entre os sexos não fosse grande, as mulheres foram maioria tanto entre aqueles que obtiveram a alforria condicional quanto entre os que a obtiveram gratuitamente. Para ambos os sexos, as alforrias condicionais foram mais que o dobro das alforrias gratuitas, proporção que predominou até a década de 1870. A partir de então, observa-se um equilíbrio na concessão das alforrias condicionais e gratuitas tanto para as mulheres como para os homens. Entre os alforriados que conquistaram a alforria com a intervenção do Estado, homens e mulheres estavam na mesma proporção. 
Faixas etárias

$0-14$

$15-29$

$30-44$

45-59

Mais de 59

\begin{tabular}{|c|c|c|c|c|c|c|c|c|c|c|}
\hline \multirow[b]{2}{*}{ Décadas } & \multicolumn{2}{|c|}{$0-14$} & \multicolumn{2}{|c|}{$15-29$} & \multicolumn{2}{|c|}{$30-44$} & \multicolumn{2}{|l|}{4} & \multicolumn{2}{|l|}{ Mais } \\
\hline & 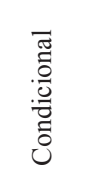 & 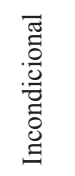 & 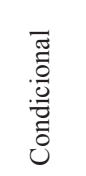 & $\begin{array}{l}\bar{\Xi} \\
0 \\
0 \\
: \\
0 \\
0 \\
\Xi\end{array}$ & 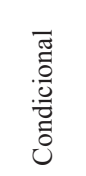 & 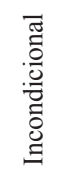 & 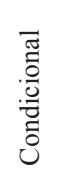 & 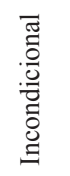 & 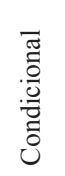 & 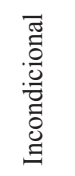 \\
\hline $1840-1849$ & $\begin{array}{c}7 \\
3,5 \%\end{array}$ & $\begin{array}{c}2 \\
1,0 \%\end{array}$ & $\begin{array}{c}3 \\
1,5 \%\end{array}$ & $\begin{array}{c}2 \\
1,0 \%\end{array}$ & $\begin{array}{c}5 \\
2,5 \%\end{array}$ & $\begin{array}{c}1 \\
0,5 \%\end{array}$ & $\begin{array}{c}3 \\
1,5 \%\end{array}$ & - & $\begin{array}{c}2 \\
1,0 \%\end{array}$ & - \\
\hline $1850-1859$ & $\begin{array}{c}12 \\
6,0 \%\end{array}$ & $\begin{array}{c}11 \\
5,4 \%\end{array}$ & $\begin{array}{c}10 \\
5,0 \%\end{array}$ & $\begin{array}{c}4 \\
2,0 \%\end{array}$ & $\begin{array}{c}8 \\
4,0 \%\end{array}$ & $\begin{array}{c}4 \\
2,0 \%\end{array}$ & $\begin{array}{c}3 \\
1,5 \%\end{array}$ & $\begin{array}{c}4 \\
2,0 \%\end{array}$ & $\begin{array}{c}2 \\
1,0 \%\end{array}$ & $\begin{array}{c}3 \\
1,5 \%\end{array}$ \\
\hline $1860-1869 *$ & $\begin{array}{c}9 \\
4,5 \%\end{array}$ & $\begin{array}{c}2 \\
1,0 \%\end{array}$ & $\begin{array}{c}9 \\
4,4 \%\end{array}$ & $\begin{array}{c}1 \\
0,5 \%\end{array}$ & $\begin{array}{c}14 \\
7,0 \%\end{array}$ & $\begin{array}{c}3 \\
1,5 \%\end{array}$ & $\begin{array}{c}3 \\
1,5 \%\end{array}$ & $\begin{array}{c}3 \\
1,5 \%\end{array}$ & $\begin{array}{c}4 \\
2,0 \%\end{array}$ & $\begin{array}{c}1 \\
0,5 \%\end{array}$ \\
\hline $1870-1879 * *$ & $\begin{array}{c}10 \\
5,0 \%\end{array}$ & $\begin{array}{c}4 \\
2,0 \%\end{array}$ & $\begin{array}{c}8 \\
4,0 \%\end{array}$ & $\begin{array}{c}2 \\
1,0 \%\end{array}$ & $\begin{array}{c}11 \\
5,4 \%\end{array}$ & $\begin{array}{c}1 \\
0,5 \%\end{array}$ & $\begin{array}{c}3 \\
1,5 \%\end{array}$ & $\begin{array}{c}3 \\
1,5 \%\end{array}$ & $\begin{array}{c}1 \\
0,5 \%\end{array}$ & $\begin{array}{c}2 \\
1,0 \%\end{array}$ \\
\hline $1880-1888 * * *$ & $\begin{array}{c}1 \\
0,5 \%\end{array}$ & - & $\begin{array}{c}8 \\
4,0 \%\end{array}$ & $\begin{array}{c}4 \\
2,0 \%\end{array}$ & $\begin{array}{c}2 \\
1,0 \%\end{array}$ & $\begin{array}{c}2 \\
1,0 \%\end{array}$ & $\begin{array}{c}2 \\
1,0 \%\end{array}$ & - & $\begin{array}{c}1 \\
0,5 \%\end{array}$ & $\begin{array}{c}1 \\
0,5 \%\end{array}$ \\
\hline & $\begin{array}{c}39 \\
19,5 \%\end{array}$ & $\begin{array}{c}19 \\
9,4 \%\end{array}$ & $\begin{array}{c}38 \\
18,9 \%\end{array}$ & $\begin{array}{c}13 \\
6,5 \%\end{array}$ & $\begin{array}{c}40 \\
19,9 \%\end{array}$ & $\begin{array}{c}11 \\
5,5 \%\end{array}$ & $\begin{array}{c}14 \\
6,9 \%\end{array}$ & $\begin{array}{c}10 \\
5,0 \%\end{array}$ & $\begin{array}{c}10 \\
5,0 \%\end{array}$ & $\begin{array}{c}7 \\
3,4 \%\end{array}$ \\
\hline Total & & & $\begin{array}{r}5 \\
25\end{array}$ & & $\begin{array}{r}5 \\
25\end{array}$ & & 11 & & & \\
\hline
\end{tabular}

Notas: *Uma alforria concedida mediante intervenção do Estado para um escravo do sexo masculino na faixa etária 30-44 anos. ** Uma escrava na faixa etária 0-14 anos foi alforriada por ser ingênua; um escravo na faixa etária 15-29 anos foi alforriado mediante intervenção do Estado.***Dois escravos na faixa etária 0-14 anos foram alforriados após intervenção do Estado. Dois escravos entre 15 e 29 anos foram alforriados seguindo a legislação abolicionista. Cinco escravos na faixa etária 30-44 anos foram alforriados mediante legislação abolicionista. Cinco escravos com idade superior a 59 anos foram alforriados mediante legislação abolicionista.

Fonte: Cartas de alforria. Arquivo da Casa Setecentista de Mariana.

Nas três primeiras faixas etárias que constam na Tabela 5, as alforrias condicionais foram bastante superiores às gratuitas, sobretudo nas faixas de 15-29 anos e de 30-44 anos — com exceção dos anos 1880, esse comportamento é percebido para todas as décadas. Para os alforriados com mais de 44 anos, a diferença entre as alforrias condicionais e as 
incondicionais não foi significativa. No caso dos escravos mais velhos (muitas vezes menos produtivos), a alforria gratuita era oferecida com maior facilidade. Segundo Eisenberg, "a alforria gratuita podia até interessar ao senhor, em certas situações. Ele alforriaria gratuitamente, por exemplo, para se livrar de obrigações legais ou morais, por mínimas que fossem, de sustentar escravos improdutivos ou indesejáveis". ${ }^{23}$

\section{Alforrias condicionais}

Nem sempre a carta de alforria traduzia-se em liberdade imediata. Conforme revelam os documentos, entre as condicionais predominavam aquelas cujos libertos ficavam atrelados ao proprietário por meio de prestação de serviços, sendo habitual que se prolongasse pelo tempo de vida do senhor. Dos 259 escravos que tiveram a alforria concedida com a prestação de serviços, 219 permaneceriam nas propriedades escravistas até a morte do proprietário. ${ }^{24}$

A condição de servir enquanto vivesse o senhor não permitia ao escravo mensurar os anos que lhe restavam de cativeiro. Em alguns casos, a condição extrapolava o tempo de vida do proprietário estendendo-se até o tempo de vida de cônjuge e filhos. Nesses termos, a carta de alforria não rompia com o sistema de trabalho obrigatório. O alforriado ainda sofria a possibilidade de revogação da carta em casos de mau comportamento. Além dos serviços prestados, era comum a condição de o escravo beneficiado pela alforria ser obediente ao proprietário durante o período de prestação de serviços, estando, em caso contrário, sujeito à anulação da alforria por ingratidão. ${ }^{25}$ Margarida, 30 anos, escrava da senhora Teresa Maria de Jesus, foi agraciada com a carta de alforria no ano de 1855 com

23 Eisenberg, "Ficando livre", p.210.

24 Em um caso, o tempo estipulado foi de 20 anos de prestação de serviços; 12 escravos alcançaram a liberdade após servirem aos donos pelo tempo que se estenderia de três a dez anos de obrigações; para outros 12, o tempo estimado foi de dois anos de serviços; cinco jovens escravos serviram até que completassem a maioridade; e, em dez casos, o tempo da prestação de serviços foi indeterminado.

25 No século XIX, as alforrias voluntárias podiam ser revogadas se um escravo fosse ingrato ou desrespeitasse um antigo dono; se ferisse ou pusesse as mãos no antigo dono; ou se não cumprisse com os compromissos impostos a ele. Segundo o código legal, a ingratidão de um liberto para com seu antigo senhor era um crime e a punição para isso era a volta à escravidão" (Mary Karasch, "A carta de alforria", in Mary Karasch (org.), A vida dos escravos no Rio de Janeiro": 1808-1850 (São Paulo: Companhia das Letras, 2000), p.591). A autora relata que 13 senhores no Rio de Janeiro tiraram a liberdade de seus ex-escravos e os devolveram à escravidão. As explicações mais comuns eram "ingratidão" e "desobediência" (Karasch, "A carta de alforria", p.469). 
a condição de prestar serviços a sua senhora até que a mesma falecesse. A carta menciona que a senhora Teresa Maria de Jesus, ao conceder a alforria, foi motivada pelo amor por tê-la criado. Entretanto, ressalta que, se, porventura, no espaço de vida que lhe restava, faltasse-lhe o respeito ou fosse-lhe ingrata, ficaria sem nenhum efeito tal esmola. ${ }^{26}$ Antônio serviu ao senhor João Paulo da Silva Costa por mais de 20 anos e, em retribuição aos cuidados, amor e obediência "com que me tem servido", ficaria livre como se de ventre livre nascesse, porém podendo o benefício da liberdade ser revogado por ingratidão. ${ }^{27}$

Mesmo sob a condição de prestação de serviços por longos períodos, a concessão da alforria era fornecida em retribuição aos bons serviços, à obediência e à fidelidade dos escravos. Foram justamente tais predicados que justificaram a alforria de Geremias (20 anos), Maria (15 anos) e Clementina (4 anos). A carta, registrada no ano de 1855 pela proprietária Ignes Pereira de Azevedo, foi concedida em retribuição aos muitos e relevantes serviços prestados com obediência e lealdade e esclarecia ser de vontade da proprietária "que logo imediatamente após minha morte fiquem estes sofridos forros e livres de toda a escravidão". ${ }^{28}$

Outra justificativa bastante comum para a concessão da alforria era o "amor por tê-lo criado", que também não garantia a liberdade imediata. Maria, de menor idade, escrava do senhor Joaquim de Freitas Ferreira, foi um desses casos. A pequena teve protocolada sua carta em $1851 \mathrm{com}$ a condição de servir a seus senhores enquanto vivessem. Joaquim de Freitas Ferreira justifica a concessão por ser Maria sua cria e

[...] pelo amor que tenho concedo por este título a alforria com a condição de viver em minha companhia e da minha mulher Feliciana Teixeira da Silva até o dia dos nossos falecimentos e neste espaço de tempo que viver em nossa companhia não poderá cobrar jornais de mim nem de minha mulher $\left[\ldots . .{ }^{29}\right.$

${ }^{26}$ Carta de Alforria (22/04/1855), Arquivo da Casa Setecentista de Mariana (ACSM), II ofício, livro de notas número 14 (1851-1855), folha 6

27 Carta de Alforria (02/03/1850), Arquivo da Casa Setecentista de Mariana (ACSM), I ofício, livro de notas número 113 (1850-1854).

28 Carta de Alforria (19/04/1855), Arquivo da Casa Setecentista de Mariana (ACSM), I ofício, livro de notas número 117 (1850-1854), folhas 25v e 26.

29 Carta de Alforria (12/05/1851), Arquivo da Casa Setecentista de Mariana (ACSM), I ofício, livro de notas número 117 (1850-1854), folha 67. 
Outros escravos poderiam vislumbrar a liberdade em menos tempo. O escravo Francisco, que teve seu papel de liberdade formalizado no ano de 1854 , ficou com a condição de trabalhar para o reverendo José Bonifácio Souza Barroso até que o mesmo conseguisse pagar suas dívidas. ${ }^{30}$ Adão, de 28 anos, pertencente ao senhor Antônio Gomes da Silva, pelos bons serviços prestados e amor, teve sua alforria outorgada no ano de 1884 com a condição de prestar serviços pelo prazo de 10 anos, findo o qual passaria a gozar de plena liberdade. ${ }^{31}$ Guilhermina, de 12 anos, escrava da senhora Genoveva Maria da Conceição, recebeu carta de liberdade em 1859 com a condição de prestar serviços a seu padrinho, senhor Antônio Firmino Xavier, até que atingisse a maioridade. ${ }^{32}$

Entretanto, com alguma frequência, as condições impostas ultrapassavam a vida dos senhores. Rosa, escrava do capitão Vicente de Paula Bernardino, foi agraciada com a carta de liberdade com a condição de prestar serviços ao proprietário até que o mesmo falecesse, após o que

servirá a menor Filomena Tomásia da Silva, filha de minha prima Francisca Maria de Jesus pelo prazo de 10 anos e findo esse prazo a referida Rosa entrará no gozo de liberdade. Estes serviços serão prestados não só a menor como poderão ser locados utilizando-se a menor do valor dos mesmos aluguéis. ${ }^{33}$

As alforrias concedidas às mulheres mediante serviço por prazo determinado envolviam uma questão controversa: a condição dos filhos nascidos no intervalo da prestação de serviços. Muitos proprietários alforriavam suas escravas condicionalmente a fim de resguardar a propriedade dos filhos dessas mulheres. As escravas Raimunda do Nascimento Lima e Raimunda Maria foram aforradas por dona Ana Joaquina do Sacramento com a condição de servi-la até a morte e, depois disso, permanecer em companhia de seu herdeiro até que completasse 40 anos. A alforria concedida em testamento no ano de 1862 continha a seguinte ressalta: "se

30 Carta de Alforria (20/03/1854), Arquivo da Casa Setecentista de Mariana (ACSM), I ofício, livro de notas número 113 (1850-1854).

31 Carta de Alforria (19/11/1884), Arquivo da Casa Setecentista de Mariana (ACSM), I ofício, livro de notas número 123 (1881-1887), folha 76v

32 Carta de Alforria (15/03/1859), Arquivo da Casa Setecentista de Mariana (ACSM), I ofício, livro de notas número 114 (1857-1861), p.46.

33 Carta de Alforria (14/08/1876), Arquivo da Casa Setecentista de Mariana (ACSM), I ofício, livro de notas número 122 (1873-1875), folha 146v. 
durante o referido prazo tivessem filhos ficariam estes cativos e aquelas libertas". ${ }^{34}$ Mary Karasch também observou esse tipo de situação para o Rio de Janeiro do começo do século XIX. Segundo a autora,

essas crianças não nasciam livres, pois os senhores tinham de registrar a alforria de crianças nascidas de uma mulher com alforria condicional, ou tinham de estipular que todos os filhos dela nasceriam livres durante o período de sua alforria condicional. ${ }^{35}$

Para 18,4\% dos escravos, a liberdade foi alcançada após o pagamento em dinheiro. ${ }^{36}$ A quantia estipulada poderia ser paga imediatamente após o acordo acerca do valor da alforria ou, como aconteceu com a maioria, em prestações. Neste último caso, enquanto o valor acordado não fosse atingido, o libertando continuaria acompanhando seus senhores e prestando-lhes serviços, conforme aconteceu com Germana, cativa do senhor João Francisco Pinheiro, que teve sua alforria avaliada em Rs 1:400\$000. No ano de 1859, quando teve sua carta registrada, Germana já havia pago Rs 1:080\$000, ficando o restante, Rs 320\$000, a ser pago

[...] com os seus serviços continuando a residir em minha casa e em minha companhia se comprometendo a pagar, na forma de serviços, cinco mil réis mensais desta data em diante e logo que preenchido o dito pagamento gozará de plena e irrevogável liberdade podendo ir para onde lhe convir". ${ }^{37}$

34 Ação de Liberdade (01/05/1872), Arquivo da Casa Setecentista de Mariana (ACSM), I Ofício, códice 452, auto 9765 , folha $1 \mathrm{v}$.

35 Karasch, "A carta de alforria", p.462.

36 Na pesquisa realizada por Mary Karasch para o Rio de Janeiro do período 1807-1831, 39\% das alforrias foram compradas. Segundo a autora, "o que havia era uma típica transação de mercado. $\mathrm{O}$ dono vendia o escravo para ele mesmo ou para outro senhor, que registrava então a alforria. Por outro lado, para o escravo havia mais do que um negócio na compra da própria liberdade" (Karasch, "A carta de alforria", pp.463-4). Na análise realizada por Enidelce Bertin, 31\% das alforrias foram concedidas mediante pagamento, em sua maioria $(71 \%)$ pelo próprio escravo ou por alguém de seu grupo de convívio. "Isso é especialmente importante porque mostra que a formação de pecúlio pelos escravos ocorreu em todo o século, apesar de esta prática somente ter sido legalmente reconhecida com a lei de 1871. A lei, no entanto, não resultou em aumento das liberdades pela via do pagamento, já que se manteve a mesma recorrência dos períodos anteriores à lei" (Bertin, Alforrias na São Paulo, p.114). Rio de Janeiro e São Paulo tiveram porcentagens mais altas que Mariana no que concerne às alforrias pagas, o que se se explica pela característica urbana daquelas localidades, que permitia ao escravo maior mobilidade e maiores oportunidades para a acumulação do pecúlio.

37 Carta de Alforria (06/04/1859), Arquivo da Casa Setecentista de Mariana (ACSM), I ofício, livro de notas número 114 (1857-1861), folha 80. 
Luiza, com idade entre 50 e 60 anos, pertencente a Maria Joaquina de São José, teve sua carta de alforria avaliada em Rs $180 \$ 000$. No momento do registro da carta, em 1845 , sua senhora já havia recebido Rs $50 \$ 000$, e o restante seria pago aos poucos com parte "dos seus jornais sem tempo determinado e obrigada a viver em minha companhia enquanto restar qualquer quantia". ${ }^{38}$

Dos 104 escravos que tiveram um valor estipulado para a alforria, 58 acertaram o pagamento em prestações. O prazo para o pagamento poderia ser longo (na maioria das vezes, indeterminado), podendo se estender até a morte do proprietário.

Entre os escravos que pagariam a alforria em prestações estavam os quartados. Segundo a definição de Douglas Libby e Afonso Alencastro Graça Filho, a quartação era uma forma relativamente frequente de obtenção de cartas de alforria.

Senhores e escravos acordavam um preço e o valor dos pagamentos anuais era estipulado. Os pagamentos normalmente duravam quatro anos, como o próprio termo quartação sugere, mas os prazos poderiam ser mais curtos ou mais longos. ${ }^{39}$

Em Mariana, foram 12 os papéis de quartamento, sendo seis registrados na década de 1840, cinco na década de 1850 e um na década de 1880 .

O caso do escravo Sabino, crioulo, de 32 anos, é um bom exemplo dessa prática. No ano de 1843, ele e sua senhora Mariana Gonçalves Ribeiro acordaram sobre as condições da quartação. Segundo o "Papel de Quartamento", Sabino ficaria liberto após o pagamento de Rs 200\$000, que deveria ser feito em quatro anos. Segundo palavras da própria senhora

[...] é muito de minha livre vontade e sem constrangimento algum que o quarto pelo preço e quantia de 200 mil réis pelo tempo de quatro anos recebendo ao fazer dessa quantia de 42 mil réis ficando a restar 158 mil reis ficando ele obrigado a trabalhar em poder de meu afilhado Antônio José de Carvalho aonde ele determinar, seguindo sempre meu afilhado

38 Carta de Alforria (06/06/1945), Arquivo da Casa Setecentista de Mariana (ACSM), I ofício, livro de notas número 112 (1844-1850), folha 33

39 Douglas Cole Libby e Afonso Alencastro Graça Filho, "Reconstituindo a liberdade - alforrias e forros na freguesia de São José do Rio das Mortes, 1750-1850”, Varia Historia, v.30 (2003), p.135. 
até completar o prazo acima declarado e pagamento sem o que não poderá gozar de liberdade concedida enquanto não satisfazer as condições aqui declaradas. ${ }^{40}$

José cabra, de 22 anos, foi quartado pela quantia de Rs 500\$000 no ano de 1851. Dessa quantia, o cativo pagou, imediatamente após o registro do papel de quartamento, o valor de Rs $100 \$ 000$, ficando o restante acertado para ser pago em serviços no valor de Rs $40 \$ 000$ por ano até preencher a quantia estipulada. ${ }^{41}$ Se conseguisse arcar com essa dívida pontualmente, José cabra ficaria liberto, de fato, em dez anos.

Muitas alforrias conferidas mediante pagamento foram realizadas por intermédio de terceiros que forneceram a quantia necessária. Nesses casos, muitas vezes, os libertos passavam a ficar subordinados a outros senhores. Esse parece ter sido o caso de José Lucas que, em 1873, teve sua alforria avaliada em Rs 1:000\$000 por seu proprietário Caetano Gomes da Silva Pontes. Após acordado o valor, José Lucas entregou ao senhor Rs $380 \$ 000$, e o restante, Rs 620\$000, foi emprestado pelo senhor José Feliciano de Almeida Pontes. O empréstimo seria pago com serviços que José Lucas ficaria a prestar por um período de cinco anos. ${ }^{42}$ Em outras situações, era um membro da família quem pagava pela liberdade do escravo: foi a mãe de Maria Crioula, de 24 anos, quem pagou a quantia de Rs 1:250\$000 para que fosse alforriada; ${ }^{43}$ a escrava Maria da Costa teve a alforria avaliada em Rs $400 \$ 000$ em 1856, quantia paga por seu marido Domiciano da Cunha. ${ }^{44}$ Eva, de 15 anos, foi alforriada por sua senhora, Feliciana Felícia da Silva, no ano de 1862, em consideração aos serviços prestados por sua mãe, também de nome Eva, e das "pequenas quantias" que paga há muitos anos em benefício da menina. ${ }^{45}$ Outras

40 Carta de Alforria (08/1843), Arquivo da Casa Setecentista de Mariana (ACSM), I ofício, livro de notas número 112 (1844-1850), folha 59.

${ }^{41}$ Carta de Alforria (10/07/1851), Arquivo da Casa Setecentista de Mariana (ACSM), I ofício, livro de notas número 113 (1850-1854), folha 34.

42 Carta de Alforria (20/02/1873), Arquivo da Casa Setecentista de Mariana (ACSM), II ofício, livro de notas número 23 (1878-1881), folha 26.

43 Carta de Alforria (04/11/1972), Arquivo da Casa Setecentista de Mariana (ACSM), I ofício, livro de notas número 122 (1873-1875), folha 110.

44 Carta de Alforria (05/04/1856), Arquivo da Casa Setecentista de Mariana (ACSM), II ofício, livro de notas número 14 (1851-1855), folha 30.

45 Carta de Alforria (01/12/1862), Arquivo da Casa Setecentista de Mariana (ACSM), II ofício, livro de notas número 15 (1859-1863), folhas 100 e 100v. 
vezes, o vínculo era espiritual. Muitos padrinhos e madrinhas esforçaramse para conquistar a liberdade de seus afilhados, como aconteceu com Margarida, de 11 anos, que, no ano de 1869, foi beneficiada com a carta de alforria passada pela senhora Henriqueta Ferreira da Rocha, depois de receber das mãos de seu padrinho, doutor Diogo Luís de Almeida Vasconcelos, a quantia de Rs $400 \$ 000$ para a liberdade. ${ }^{46}$

\section{Alforrias incondicionais}

A prestação de serviços e/ou o pagamento de quantias em dinheiro foram óbices para que muitos homens e mulheres que conquistaram suas cartas de alforria fossem considerados, de fato, "libertos como se de ventre livre nascessem". Entretanto, para 166 alforriados (29,4\% do total), a carta de liberdade foi fornecida sem ônus algum. Nesses casos, justificativas como "pelo amor que lhe tenho" ou "pelos bons serviços prestados com lealdade" estavam comumente presentes. ${ }^{47}$ Ana, de nação congo, foi uma dessas pessoas que receberam a carta de alforria incondicional em retribuição aos serviços prestados. Sua senhora, Ponciana Cândida de São José, ao registrar a carta no ano de 1841, fez questão de ressaltar que a liberdade era pelo fato de a escrava sempre "ter me servido bem e fielmente". Por isso, "[declaro] de hoje em diante liberta de toda a escravidão como se nascesse liberta do ventre de sua mãe e por tal poderá tratar de sua vida por onde muito quiser". ${ }^{48}$ Luiza, de nação rebola, foi alforriada em 1847 por sua proprietária, Ana Maria de Jesus, por tê-la servido "com satisfação e caridade" durante sua moléstia. ${ }^{49}$

46 Carta de Alforria (1869), Arquivo da Casa Setecentista de Mariana (ACSM), II ofício, livro de notas número 19 (1869-1872), folha 6v.

47 Analisando as alforrias incondicionais, também chamadas de gratuitas, Eisenberg argumenta que, de fato, elas nunca aconteciam de maneira plena: "Mesmo sem ter que pagar dinheiro ou prestar serviços para receber a alforria, o indivíduo durante a sua vida de escravo já entregara valores para o senhor, sem que tivesse havido uma contrapartida de valores iguais entregues ao escravo" (Eisenberg, "Ficando livre", p.210). Jacob Gorender também afirma que a alforria nunca foi gratuita. Analisando as explicações para a concessão da alforria, habitualmente mencionadas nas cartas como "bons serviços", "lealdade", "obediência", ele concluiu que "a expectativa de liberdade condicionou o comportamento do escravo beneficiado" (Jacob Gorender, O escravismo colonial, São Paulo: Ática, 1985, p.356).

48 Carta de Alforria (06/10/1841), Arquivo da Casa Setecentista de Mariana (ACSM), I ofício, livro de notas número 112 (1844-1850), folha 27.

49 Carta de Alforria (31/03/1947), Arquivo da Casa Setecentista de Mariana (ACSM), I ofício, livro de notas número 112 (1844-1850), folha 40v. 
A alforria como retribuição aos serviços prestados favoreceu sobretudo os mais velhos. O casal Liberato, de 70 anos, e Maria Paula, de 50 anos, após muito tempo de bons serviços e dedicação, foi agraciado com a liberdade, sem ônus algum, pelo senhor Francisco Antônio Gonçalves Leal no ano de $1861 .{ }^{50}$ Guardiano, de 60 anos, tornou-se forro pelo Barão de Itabira "por ter me servido com amor e lealdade". ${ }^{51}$ Francisca, de 50 anos, foi beneficiada com a alforria, sem ônus, no ano de 1870 , por ter fornecido aos seus proprietários, Joaquim Inácio Ramos e sua mulher Manuela Joaquina do Espírito Santo, muitas crias. ${ }^{52}$

Houve também casos de alforrias gratuitas para escravos com graves enfermidades. Antônio Casimiro de Souza e José Florêncio de Souza resolveram, em 1855, alforriar sua escrava Ana de Souza,

[...] por se achar muito doente com uma enfermidade mortal, motivo que não poderá ter sua avaliação para ser partilhada entre os herdeiros que somos quatro herdeiros e como a dita escrava até agora não tem tido melhoras nenhum cujas partes que nós houvemos na dita cedemos em sua liberdade quando ela tenha alguma saúde..$^{53}$

A menina Rita, que foi escrava da senhora Eulina Maria de Mello, recebeu a carta de alforria livre de qualquer condição em 1856, graças ao "grande amor e parentesco espiritual" que a proprietária tinha por ela. ${ }^{54} \mathrm{O}$ amor foi a alegação comum a alforrias de outras crianças sem ônus algum. ${ }^{55}$

50 Carta de Alforria (01/01/1961), Arquivo da Casa Setecentista de Mariana (ACSM), I ofício, livro de notas número 118 (1864-1868), folhas 117 e $117 \mathrm{v}$.

${ }^{51}$ Carta de Alforria (30/11/1855), Arquivo da Casa Setecentista de Mariana (ACSM), II ofício, livro de notas número 14 (1851-1855), folha 1

52 Carta de Alforria (25/04/1870), Arquivo da Casa Setecentista de Mariana (ACSM), I ofício, livro de notas número 120 (1867-1872), folha 57.

53 Carta de Alforria (14/04/1855), Arquivo da Casa Setecentista de Mariana (ACSM), II ofício, livro de notas número 14 (1851-1855), folhas $5 \mathrm{v}$.

54 Carta de Alforria (14/01/1856), Arquivo da Casa Setecentista de Mariana (ACSM), I ofício, livro de notas número 117 (1854-1857), folhas 43-43v.

55 Almeida constata, para o período $1800-1850$, em Rio de Contas, $67,3 \%$ de alforrias incondicionais concedidas a escravos com até 12 anos e, para 1850-1871, porcentagem menor, mas ainda bastante alta, $48,5 \%$. Analisando esses dados, ressalta ser "muito provável que algumas das crianças alforriadas gratuitamente tenham permanecido no cativeiro com suas mães, não representando um ônus para o senhor alforriar um escravo sob tais circunstâncias" (Almeida, "Da prática costumeira", p.172). 
Assim foi com o pequeno Melchiades, descrito com pouca idade, que recebeu a carta pelo amor que dona Maria Carolina lhe dedicava. ${ }^{56}$

Em algumas ocasiões, o parentesco foi a justificativa. Angélica, filha de Maria dos Anjos e Luís pardo, escrava de dona Joaquina Cláudia de São José, foi alforriada, em 1840, "em razão dos bons serviços e ser ainda minha parenta". ${ }^{57}$ Maria dos Anjos teve mais dois filhos alforriados, Maria e Francisco, descritos como filhos de José da Silva. Dona Joaquina Cláudia de São José também concedeu carta para ambos os petizes, sem, porém, mencionar qualquer parentesco. Tomando como hipótese que seu parentesco com Angélica se desse por parte de Luís pardo, deduzse que isto a livrasse da obrigação moral de aforrar incondicionalmente Francisco e o mantivesse prestando serviços até sua morte, como de fato o fez, apesar de libertar sem ônus a pequena Maria. ${ }^{58}$ A cativa Bárbara recebeu a carta de liberdade no ano de 1856 de seu senhor, Felipe Alves de Magalhães, "[por ter alimentado minha filha, Maria Benedita Alves de Castro,] nos seus peitos e por lhe ter prestado os serviços domésticos com todo amor e caridade a esta minha filha [...] lhe confiro a liberdade como se de ventre livre nascesse e poderá desde já entrar no gozo dela". ${ }^{59}$

Os cativos cujas alforrias foram obtidas sem nenhuma condição imposta estariam, de fato, livres da escravidão? As cartas de liberdade não nos permitem avançar sobre a questão. Entretanto, 18 escravos tiveram a carta de liberdade concedida sem ônus, sendo alforriados apenas em "partes" "uma parte", "duas partes", "um terço". Isto ocorria nos casos em que o

56 Carta de Alforria, Arquivo da Casa Setecentista de Mariana (ACSM), I ofício, livro de notas de 1807 a 1831 localizou $20,1 \%$ dos escravos sendo alforriados de maneira incondicional. Entre as especulações sobre as razões que levavam os senhores a alforriarem escravos sem nenhuma condição, Karasch sugere que alguns senhores intencionavam com essa atitude "evitar as despesas de cuidar de escravos idosos e doentes" (Karasch, "A carta de alforria", p.462). Continuando, comenta que "além dos doentes e idosos, outro tipo de escravo que os senhores alforriavam incondicionalmente eram as crianças. Na maioria dos casos, o senhor não admitia ser o pai da criança, mas às vezes registrava-se que o pai estava libertando a criança para apaziguar sua consciência. Havia senhores que também alforriavam incondicionalmente suas amantes escravas, em especial se fossem mães de seus filhos" (Karasch, "A carta de alforria", p.463).

57 Carta de Alforria (06/10/1848), Arquivo da Casa Setecentista de Mariana (ACSM), I ofício, livro de notas número 112 (1844-1850), folhas 79v e 80.

58 Carta de Alforria (06/09/1848), Arquivo da Casa Setecentista de Mariana (ACSM), I ofício, livro de notas número 112 (1844-1850), folha 79.

59 Carta de Alforria (10/04/1856), Arquivo da Casa Setecentista de Mariana (ACSM), I ofício, livro de notas número 117 (1854-1857), folhas 88 e 88v. 
escravo pertencia a mais de um senhor e, nem sempre todos concordavam na concessão da alforria. Veja-se o exemplo da escrava Maria, de 11 anos, que, no ano de 1867, recebeu a carta de liberdade das mãos de Tereza Maria de Souza, que possuía dois terços dessa escrava e apenas nesses dois terços a menina ficaria "livre como se de ventre livre nascesse". ${ }^{60}$

Muitos escravos, mesmo recebendo alforria sem ônus algum, continuaram vivendo nas propriedades onde foram cativos. A escrava Efigênia Maria da Cruz, de 32 anos, recebeu a carta de alforria no ano de 1854 das mãos da senhora Clara Felícia de Jesus "porque a mesma escrava seja minha afilhada e tenha prestado bons serviços", com a ressalva de que, mesmo forra, “continua a residir em minha companhia [e] não poderá em tempo algum reclamar salário algum, pois a beneficência que lhe outorgo é superior a tudo". ${ }^{61}$ As crianças escravas que receberam a alforria poderiam permanecer com seus antigos senhores até chegarem à maioridade. Foi o caso do pardinho Barbané, descrito com pouca idade, aforrado sem nenhuma condição, no ano de 1856, pelo senhor José Francisco Ferreira Gualda, o qual depois de liberto "fica entregue para sua educação a minha filha dona Genoveva". ${ }^{2}$

Algumas cartas mencionaram a possibilidade de os libertos serem ressarcidos por seu trabalho. A escrava Bárbara, já aqui citada por ter recebido a alforria depois de conceber cinco filhos para a escravaria do Barão do Pontal, foi liberta sem nenhuma condição no ano de em 1855. Na carta, seu senhor esclarece que Bárbara "poderá residir nesta ou outra minha casa enquanto me agradar o seu serviço e ela quiser, fazendo qualquer serviço de casa ou da roça como tem até o presente e recebendo a porção de 14 mil réis anuais e quando ela queira retirar-se de minha casa e fazenda receberá mais 20 mil réis para seus arranjos". ${ }^{63}$

${ }^{60}$ Carta de Alforria (14/03/1867), Arquivo da Casa Setecentista de Mariana (ACSM), I ofício, livro de notas número 118 (1864-1868), folha $157 \mathrm{v}-158$.

${ }_{61}$ Carta de Alforria (23/04/1854), Arquivo da Casa Setecentista de Mariana (ACSM), II ofício, livro de notas número 12 (1851-1855), folha 77

62 Carta de Alforria (20/07/1856), Arquivo da Casa Setecentista de Mariana (ACSM), II ofício, livro de notas número 14 (1851-1855), folha 31.

${ }_{63}$ Carta de Alforria (25/02/1855), Arquivo da Casa Setecentista de Mariana (ACSM), II ofício, livro de notas número 14 (1851-1855), folha 34v. O Barão do Pontal também aparece nas fontes consultadas alforriando a escrava Feliciana parda no ano de 1846, porém com a condição de servi-lo pelo tempo de dez anos; findo esse período, "ficará liberta como se nascesse de ventre livre podendo ficar no serviço desta casa querendo enquanto me agradar e a meus sucessores recebendo desde esse dia a porção anual de 15 mil réis" (Carta de Alforria (25/03/1846), Arquivo da CSM, II ofício, livro de notas número 14 (1851-1855), folha 90). 
Embora as fontes não permitam afirmar que a maioria dos escravos alforriados incondicionalmente em Mariana continuasse vivendo nas propriedades dos seus antigos senhores, a julgar pela historiografia, é possível que muitos permanecessem em condições próximas àquelas que antecediam a alforria. Fossem mães, pais, crianças, idosos, moribundos e mesmo adultos produtivos e desimpedidos, quem, afinal, tendo vivido em cativeiro boa parte da vida e pertencendo às mais baixas categorias sociais, teria guarida garantida fora dali, ou condições financeiras para adquirir meios de produção?

Conforme ressalta Kátia Mattoso, as poucas alternativas de vida sujeitavam os libertos à dependência de seus antigos senhores, levando-os a permanecer em sua companhia. Dessa forma, a liberdade não significava a ruptura das relações entre senhores e escravos. $\mathrm{O}$ alforriado que permanece nos domínios do antigo senhor

[...] vê garantido seu futuro e afastado o medo do desconhecido; sente-se protegido. Contudo, de imediato, sua liberdade é bem precária, econômica e socialmente. Ele continua a pertencer ao mundo bem fechado gravitando em torno do seu antigo senhor, que continua a ser para ele um modelo de comportamento, um possível refúgio, uma espécie de boia à qual poderá sempre agarrar-se em caso de necessidade. O escravo liberto está no sopé da escala social agrária e mal se distingue da massa dos escravos, pois, embora liberto, continua a dever a seu antigo senhor a mesma obediência, a mesma humildade, as mesmas satisfações de antes, a fim de viver em paz, de conservar o que tanto lhe custou obter. Para livrar-se de seu antigo proprietário, para tornar-se independente, seria preciso partir para muito longe da fazenda e cortar todos os vínculos que o prendem ao seu mundo de escravo.$^{64}$

\section{Alforrias concedidas pelo Estado}

Além da libertação do ventre das escravas, a lei de 1871, no seu artigo $4^{\circ}$, garantia os direitos de o escravo acumular e utilizar seus pecúlios para a compra da própria alforria. A lei garantia-lhe, ainda, o direito de ter seu valor de alforria estabelecido pela Justiça. Assim, ao falharem as negociações com os senhores, havia a possibilidade de o cativo solicitar

${ }^{64}$ Kátia de Queirós Mattoso, Ser escravo no Brasil, São Paulo: Brasiliense, 1990, p.203. 
a mediação da Justiça com o depósito e arbitramento do valor de sua alforria. A lei de 1871 estabeleceu também o Fundo de Emancipação - composto por taxas e impostos sobre os escravos, loterias, multas e contribuições -, que proveria a alforria gradual dos escravos existentes no Império. A fim de possibilitar a identificação dos escravos aptos a receber a liberdade, foi determinado, no artigo $8^{\circ}$, que se fizesse a "matrícula especial de todos os cativos existentes no Império, com declaração de nome, sexo, estado civil, aptidão para o trabalho e filiação de cada um, se for conhecida". O mesmo artigo, no parágrafo $2^{\circ}$, deliberava que "os escravos que, por culpa ou omissão dos interessados, não forem dados à matrícula até um ano depois do encerramento desta, serão por este fato considerados libertos". ${ }^{65}$

A partir da relação de escravos matriculados, estabelecia-se a classificação dos cativos que seriam beneficiados pela alforria. A lei foi precisa na prioridade a quem favorecer com a libertação: os membros da mesma família que pertencessem a senhores diferentes; casais que tivessem filhos nascidos livres em virtude da lei ou menores de oito anos; cônjuges que tivessem filhos livres menores de 21 anos; casais com filhos menores escravos; mães com filhos menores escravos; casais sem filhos menores; indivíduos (mãe ou pai) com filhos livres; e cativos entre 15 e 50 anos, iniciando-se pelos mais jovens do sexo feminino até os mais velhos do sexo masculino. Concluída essa etapa, os recursos do fundo seriam aplicados na compra das alforrias de acordo com o valor declarado ou arbitrado para cada escravo.

O parágrafo $4^{\circ}$ do artigo $4^{\circ}$ da lei de 1871 concedia, ao escravo em condomínio libertado por um de seus senhores, o direito à sua alforria, indenizando os demais pelo seu valor. Caso o pagamento fosse feito em serviço, esse prazo não seria superior a sete anos. Essa lei decretou também o fim da revogação da alforria por ingratidão ou por descumprimento das condições estabelecidas para a liberdade plena e deu aos escravos a possibilidade de denunciar irregularidades e arbitrariedades

${ }^{65}$ Luiz de Souza da Silveira, Annotações à lei, n. 2040, de 28 de setembro de 1871: seguidas de todas as leis e decretos relativos a escravidão, tráfico de africanos, locação de serviços, avisos e decisões dos tribunaes, e de um formulário de todas as acções, Maranhão: Frias, 1876. Disponível em: <http://www2.senado.leg.br/bdsf/bitstream/handle/id/185618/000097348.pdf?sequence=1>, p.15. 
concebidas no meio do cativeiro. Uma vez constatadas as ilegalidades, a Justiça determinaria a alforria da vítima.

Essa legislação introduziu ao âmbito legal questões anteriormente solucionadas à luz do direito costumeiro. ${ }^{66}$ A partir de então, o Estado passou a atuar no que era considerado propriedade privada, interferindo diretamente nas relações entre senhores e escravos. Uma vez selecionados pelo Fundo de Emancipação ou possuindo pecúlio correspondente ao seu valor, o escravo podia vislumbrar a liberdade, ainda que à revelia de seu senhor. Neste último caso, os escravos teriam de percorrer o caminho judicial para a obtenção da alforria por meio das chamadas ações de liberdade.

Segundo Manuela Carneiro da Cunha, até a lei de 1871, o Estado só havia interferido na relação senhor/escravo em situações de caráter excepcional, como para recompensar escravos que haviam lutado na Guerra do Paraguai e na de Independência da Bahia. ${ }^{67}$ Mary Karasch, analisando a prática da alforria no Rio de Janeiro na primeira metade do século XIX, ressalta que, além dos casos de guerras e revoltas, o governo alforriava escravos tratados cruelmente por seus senhores.$^{68}$ Existiram também casos de escravos que procuraram a Justiça por terem sido ilegalmente escravizados. Keila Grinberg, ao analisar as ações de liberdade anteriores a 1871 na Corte de Apelação, conclui que houve interferência do Estado nas relações escravistas antes da Lei do Ventre Livre, discordando da tese de Cunha de que, antes de 1871, o direito positivo não era aplicável aos escravos em sua relação com os senhores. ${ }^{69}$ Segundo Grinberg, as ações de liberdade foram abertas por escravos desde o final do século XVIII pelos mais diversos motivos: a alegação de que a mãe ou avó já haviam sido libertadas; o abandono pelos senhores e os castigos excessivos; a tentativa frustrada de compra da alforria e a alegação de que chegaram ao Brasil após o fim do tráfico negreiro. Pode-se acrescentar ainda, após 1871, a falta da matrícula ou a falsificação desse documento e o desacordo com relação ao valor da alforria.

${ }^{66}$ Manuela Carneiro da Cunha, "Sobre os silêncios da lei: lei costumeira e lei positiva nas alforrias de escravos no Brasil no século XIX", in Manuela Carneiro da Cunha (org.), Antropologia do Brasil (São Paulo: Brasiliense, 1986).

${ }^{67}$ Cunha, "Sobre os silêncios da lei".

68 Karasch, "A carta de alforria", pp.443-6.

${ }^{69}$ Keila Grinberg, Liberata - a lei da ambiguidade: as ações de liberdade da Corte de Apelação do Rio de Janeiro no século XIX, Rio de Janeiro: Relume Dumará, 1994, pp.45-7. 
Em Mariana, foram registradas 28 cartas de alforria mediante intervenção do Estado, apenas uma delas lavrada antes de 1871. Era o ano de 1866, quando Bernardino recebeu a carta de alforria das mãos do cônego Joaquim Antônio de Andrade Benfica, primeiro substituto do juiz municipal e de órfãos. Após a morte de seu proprietário, o coronel-mor João Paulo da Silva Costa, Bernardino, pardo, de 35 anos, por estar muito doente, requereu à Justiça sua liberdade, alegando que possuía o correspondente a seu valor estabelecido na avaliação descrita no inventário post-mortem do seu antigo senhor, Rs 300\$000. Analisando-se a carta de liberdade, conhece-se o procedimento seguido pelo juiz substituto para a concessão da alforria. Diz o cônego Joaquim Antônio de Andrade Benfica que,

[...] procedendo-se ao inventário dos bens do capitão-mor João Paulo da Silva Costa casado que foi com dona Rita Soares da Silva Costa foi descrito e avaliado o escravo Bernardino, pardo, muito doente, de hipotrofia de trinta e cinco anos em trezentos mil réis e apresentando o mencionado escravo a quantia porque foi avaliado pedindo para ser libertado, mandei ouvir o curador geral de órfãos e o curador dos herdeiros ausentes os quais exararam e mandando depositar a quantia em mão de José Manuel Nolasco Pimenta mandei passar a presente carta de liberdade ao mesmo Bernardino o qual de hoje em diante ficará gozando da mesma. Dada e passada nesta leal cidade de mariana aos trinta e um de outubro de $1866 .^{70}$

Não foi localizado o processo que deu origem a manumissão do escravo Bernardino, porém, é provável que, diante de sua precária condição de saúde - sofria de hipotrofia muscular que o tornava incapaz para o trabalho - e por possuir a quantia correspondente a seu valor, os herdeiros do capitão-mor João Paulo da Silva Costa não tenham se manifestado contrários à liberdade desse escravo doente. ${ }^{71}$

As outras 27 cartas outorgadas por intermediação do Estado tiveram, em suas justificativas, alguma ligação com as leis posteriores a 1871.

70 Carta de Alforria (31/11/1866), Arquivo da CSM, I ofício, livro de notas número 118 (18641868), folhas 142 e $142 \mathrm{v}$.

71 Embora essa seja a única carta de alforria registrada antes da lei de 1871, que resultou na interferência do Estado, outras ações de liberdade foram abertas no período 1850-1870 por escravos que se julgavam em injusto cativeiro. Do total das 101 ações, 34 foram iniciadas antes de 1871 e 67 após a lei de 1871 . 
Examinando-se o texto das cartas, depreende-se que, em 11 ocasiões, a Justiça admitiu a alforria por ausência na lista de matrícula; em sete casos, a liberdade resultou do Fundo de Emancipação; quatro foram por ações de liberdade em que se mencionava a existência de pecúlio dos escravos; e, em cinco outros, a alforria decorreu da Lei dos Sexagenários.

José dos Reis, de 45 anos, foi um desses escravos que recorreram à Justiça a fim de conquistar a alforria. A ação de liberdade impetrada por ele foi aberta em 1874 e transcorreu de forma rápida, com sentença favorável à manumissão no mesmo ano. Também é do ano de 1874 o registro de sua carta de liberdade realizado no II ofício do termo de Mariana, cujo texto revela que a concessão da liberdade resultou do fato de o escravo não ter sido matriculado no tempo hábil por seu proprietário, Frederico Carlos de Sá. O tabelião público, Antônio José da Costa Pereira, responsável pela feitura do papel de liberdade concedido a José dos Reis, afirma:

[...] em meu poder e cartório se acham os autos da ação de liberdade de José dos Reis e neles a folhas sete se encontram a sentença do teor seguinte. Visto pelas certidões negativas de folha e folha se prova que o escravo José dos Reis não se acha matriculado em face do artigo $8^{\circ}$ parágrafo $2^{\circ}$ da lei de 28 de setembro de 1871 , artigo $19^{\circ}$ do Decreto de $1^{\circ}$ de dezembro do mesmo ano e $87^{\circ}$ parágrafo $2^{\circ}$ do Decreto de 13 de novembro de 1872 julgo o mesmo liberto e mando que se lhe dê certidão deste que se lhe servirá de título de liberdade de que gozará plena e inteiramente. ${ }^{72}$

Segundo determinação da lei de 1871, como já referido, todos os escravos do Império deveriam ser matriculados nas coletorias municipais, sendo considerados livres aqueles cujo registro não se efetivasse dentro do prazo de um ano. Na alegação descrita no início do processo aberto pelo escravo José dos Reis, por meio do seu curador, doutor Theophilo Pereira da Silva, informa que possui direito à liberdade por se encontrar em estado de abandonado:

Diz José dos Reis, por seu curador abaixo assinado, que pertencendo ele

72 Carta de Alforria (10/07/1874), Arquivo da Casa Setecentista de Mariana (ACSM), I ofício, livro de notas número 122 (1873-1875), folha 63. 
a Frederico Carlos de Sá foi para aqui trazido por seu senhor há 20 anos mais ou menos e retirando-se este logo depois para a província da Bahia d'onde vieram e são naturais, deixou o suplicante nesta cidade de 18 a 20 anos para trabalhar e com o produto de seus jornais pagar algumas dívidas que contraíra durante sua estadia aqui. O suplicante saldou há muitos anos essas contas, e tem continuando a permanecer e residir no arraial da Passagem desta cidade tendo economia própria e sem que jamais seu ex-senhor o tenha chamado para si. $^{73}$

Atestando o abandono, o curador afirma que José dos Reis não foi matriculado na relação geral dos escravos nem por Frederico Carlos de Sá nem por qualquer outro cidadão, conforme revela a certidão negativa fornecida pela Coletoria das Rendas Gerais do Município de Mariana. Pelo total abandono, segundo o argumento do curador, estaria José dos Reis liberto: "é evidente que o suplicante tem total direito de ser declarado livre: $1^{\circ}$ ) pela prescrição do domínio; $2^{\circ}$ ) pelo abandono em que há muitos anos vive o suplicante não tendo o dito seu ex-senhor nem ao menos matriculado o dito escravo" ${ }^{74}$ Baseando-se nesses fatos, o curador solicita ao "doutor juiz de direito para julgar a liberdade do suplicante por sentença em virtude da lei, servindo ao suplicante da carta de liberdade". Em 3 de julho de 1874, a sentença favorável à liberdade de José dos Reis foi decretada. Por força das disposições da lei de 1871 e do Decreto n ${ }^{0} 5.135$, de 1872, estaria

o suplicante liberto, pois que residindo há muito no município desta cidade como prova o atestado não foi matriculado na relação geral dos escravos por seu senhor ou por pessoa que legalmente pudesse fazê-lo. Apresentou-se como prova o atestado visto que não foi matriculado na relação geral dos escravos. ${ }^{75}$

Após a sentença, o juiz mandou passar-lhe a certidão de liberdade "que lhe servirá de título de liberdade de que gozará plena e inteiramente", o que ocorreu no mesmo dia da concessão da sentença.

73 Ação de Liberdade (16/06/1874), Arquivo da Casa Setecentista de Mariana (ACSM), II ofício, códice 316 , auto 7560 , folha 3 .

74 Ação de Liberdade (16/06/1874), Arquivo da Casa Setecentista de Mariana (ACSM), II ofício, códice 316 , auto 7560 , folha 3 .

75 Ação de Liberdade (16/06/1874), Arquivo da Casa Setecentista de Mariana (ACSM), II ofício, códice 316 , auto 7560 , folha $3 \mathrm{v}$. 
A já mencionada carta de alforria concedida à família de Antônia Pires, em 1874, também foi resultado de uma ação de liberdade. Após a intermediação da Justiça, 11 escravos deixaram de pertencer ao senhor Antônio Fernandes Barroso: Antônia Pires (48 anos), seus filhos e netos - Ana Pires (28 anos), Isabel Pires (25 anos), Rita Pires (16 anos), Juventina Pires (12 anos), Faustino Pires (20 anos), José Pires (14 anos), Clemente Pires (12 anos), João Pires ( 9 anos) — e seus irmãos Mariana Pires (30 anos) e Miguel Pires (50 anos).

Manuel Basílio do Espírito Santo, escrivão responsável pela carta de alforria concedida à família de Antônia Pires certifica que

[...] em meu poder e cartório se acha um auto de liberdade de Antônia Pires e outros escravos que foram de Antônio Fernandes Barroso e neles a folhas seis se acha a sentença do teor seguinte. Em virtude do artigo $8^{\circ}$, parágrafo $2^{\circ}$ da Lei de 28 de setembro de 1871 e Decreto de $1^{\circ}$ de dezembro de 1871 e tendo em vista a certidão negativa a folhas cinco verso e folhas seis considerando libertos os escravos Antônio Pires, Isabel, Rita Pires, Juventina Pires, Faustino Pires, José Pires, Clemente Pires, João Pires, Mariana Pires, Miguel Pires, assim julgando mando que se lhes deem certidão desta para valer como carta de liberdade de que terão pleno gozo. Mariana, 23 de junho de $1874 .^{76}$

A partir dessa ação de liberdade fica-se sabendo que Antônia Pires e seu grupo familiar sempre foram escravos de Antônio Fernandes Barroso, tendo nascido seus filhos e netos na propriedade daquele senhor, com quem viveram até seu falecimento em 1857. Segundo a história narrada por Antônia Pires, o senhor Antônio Fernandes Barroso teria declarado verbalmente, em presença de várias pessoas, que, após sua morte, a família de Antônia Pires ficaria livre. Entretanto, os herdeiros do senhor Barroso, desconsiderando a promessa e julgando-se no direito aos suplicantes, tentaram chamá-los ao cativeiro. Para defender a liberdade, Antônia Pires, por intermédio de um curador, recorreu à Justiça no ano de 1863. Segundo o argumento descrito pelo defensor,

[...] estão os suplicantes forros ou livres por força das determinações

76 Carta de Alforria (23/07/1974), Arquivo da Casa Setecentista de Mariana (ACSM), I ofício, livro de notas número 122 (1873-1875), folhas 62-62v. 
positivas do artigo $8^{\circ}$, parágrafo $2^{\circ}$ da lei número 2.040 de 28 de setembro de 1871 , decreto número 4.835 de $1^{\circ}$ de dezembro de 1872 ; porquanto, todas essas leis e regulamentos conferem a liberdade aos escravos que não tiverem sido matriculados nas coletorias dos municípios de suas residências até o dia 30 de setembro de 1873 . Pela certidão junto provam os suplicantes que não se acham matriculados como escravos. Assim pois são livres por força das leis citadas. ${ }^{77}$

O advogado dos suplicantes alegou a existência de casos semelhantes que poderiam fundamentar outros tantos processos de liberdade nos tribunais brasileiros, nos quais se embasou para pedir a certidão negativa que comprovava a ausência da matrícula desses escravos e legitimava sua liberdade, como um processo aberto na Bahia, em que o pardo Emídio, não tendo sido matriculado por seu senhor no prazo legal, requereu que fosse julgado livre por força das leis. Para tanto,

Juntou somente certidão negativa da matrícula e o juiz competente por sentença julgou-o livre independente de mais provas, discussões ou audiência de seu senhor. Este apelou da sentença para a relação daquela capital, porém não foi aceito tal recurso pelo juiz [...]. Achamos relatado este ocorrido a página 559 do Jornal de Jurisprudência "O Direito" que se publica na Corte. ${ }^{78}$

Como, de fato, não havia registro da matrícula de nenhum dos membros da família de Antônia Pires, a jurisprudência foi favorável aos suplicantes:

[...] em vista dos artigos $8^{\circ}$, parágrafo $2^{\circ}$ da lei de 28 de setembro de 1871 e decreto de $1^{\circ}$ de dezembro de 1871 , e tendo em vista a certidão negativa a folhas $5 \mathrm{v}, 6 \mathrm{e} 6 \mathrm{v}$ considero libertos os escravos Antônia Pires, Ana Pires, Isabel, Rita Pires, Juventina Pires, Faustino Pires, José Pires, Clemente Pires, João Pires, Mariana Pires, Miguel Pires, assim julgado, mando que se lhes dê a certidão desta para valer como carta de liberdade de que terão pleno gozo. Mariana, 23 de junho de $1874 .{ }^{79}$

77 Ação de Liberdade (10/10/1863), Arquivo da Casa Setecentista de Mariana (ACSM), I ofício, códice 404, auto 8839 , folha $2 \mathrm{v}$.

78 Ação de Liberdade (10/10/1863), Arquivo da Casa Setecentista de Mariana (ACSM), I ofício, códice 404, auto 8839 , folha 3 .

79 Ação de Liberdade (10/10/1863), Arquivo da Casa Setecentista de Mariana (ACSM), I ofício, códice 404, auto 8839 , folha 6 . 
Após a sentença, Miguel Pires, José Pires, Faustino Pires, Isabel Pires e Mariana Pires requereram na Justiça os valores a que faziam jus pelos serviços prestados à companhia mineradora Dom Pedro North Del Rei, que lavrava ouro nos arredores da sede do município de Mariana. Também nessa ação os parentes de Antônia Pires foram bem sucedidos e, dois meses após a reivindicação, receberam Rs 1:900\$000, valor bastante considerável e que devia corresponder a um grande período de tempo ${ }^{80}$

Jeremias Damasceno, que vivia no Seminário Episcopal de Mariana como escravo, mas era propriedade do capitão José Francisco de Mendonça, residente na cidade de São João del Rei, foi outro que conquistou a carta de alforria depois de lutar na Justiça por sua liberdade. Tendo acumulado pecúlio durante o período em que permaneceu em companhia dos padres, pretendia indenizar seu senhor pelo preço correspondente a seu valor, conforme descrito pela tabela elaborada pela Lei $\mathrm{n}^{\mathrm{o}} 3.279$. Conforme revela o documento lavrado em Mariana, no ano de 1887, a emancipação foi reconhecida após o pagamento do valor correspondente ao descrito em sua avaliação.

O tenente coronel Eleutério de Souza Novais juiz municipal e dos órfãos substituto com jurisdição plena no município da cidade de Mariana [...] faço saber aos que a presente carta de liberdade virem que havendo Jeremias Damasceno escravo do capitão José Francisco de Mendonça residente em São João del Rei depositado na coletoria das rendas gerais desta cidade a quantia de 600 mil réis em notas do Império na forma de preço de seu valor conforme a tabela n. 3279 de 28 de setembro de 1885 artigo primeiro, parágrafo terceiro tendo requerido sua liberdade e mandei passar com a qual entraria no gozo de sua liberdade como se nascesse de ventre livre. ${ }^{81}$

A ação de liberdade, promovida por Jeremias, baseava-se na legislação de 1885, conhecida como Lei Saraiva-Cotegipe ou Lei dos Sexagenários. $\mathrm{O}$ artigo $1^{\circ}$ dessa lei, em seu parágrafo $3^{\circ}$, estabelecia uma tabela com o preço dos escravos, que passava a ser fixado em ra-

80 Ação de Liberdade (10/10/1863), Arquivo da Casa Setecentista de Mariana (ACSM), I ofício, códice 404 , auto 8839 , folha 9 .

${ }_{81}$ Carta de Alforria (24/03/1887), Arquivo da Casa Setecentista de Mariana (ACSM), Carta de alforria, I ofício, livro 123 (1881-1887), folhas 100v, 101. 


\section{Tabela 6 - Preço dos escravos fixados segundo idade e gênero}

de acordo com a Lei n $^{\circ}$ 3.270, de 1885

\begin{tabular}{lcl}
\hline Idade & Homens & Mulheres \\
\hline Menores de 30 anos & Rs $900 \$ 000$ & Rs $675 \$ 000$ \\
Entre 30 e 40 anos & Rs $800 \$ 000$ & Rs $600 \$ 000$ \\
Entre 40 e 50 anos & Rs $600 \$ 000$ & Rs $450 \$ 000$ \\
Entre 50 e 55 anos & Rs 400\$000 & Rs 300\$000 \\
Entre 55 e 60 anos & Rs 200\$000 & Rs 150\$000 \\
\hline Fonte: Lei no 3.270, de 28 de setembro de 1885. Coleção das Leis \\
do Império do Brasil. Rio de Janeiro, Typografia Nacional.
\end{tabular}

zão da idade e do gênero - as escravas valeriam 25\% menos do que seus correspondentes masculinos. ${ }^{82}$ Esse artigo visava a acabar com o dispositivo do arbitramento e com as tensões que essas ações judiciais criavam nas relações entre senhores e escravos. A Tabela 6 apresenta os valores determinados pela lei.

Por sua matrícula, fica-se sabendo que Jeremias tinha a idade de 40 anos completos, sendo seu valor correspondente à quantia de Rs $600 \$ 000$. Uma vez declarado o valor do escravo e sabendo-se que possuía o correspondente ao seu preço - que, segundo o processo, lhe fora fornecido pelo padre Antônio Cardoso Damasceno - , estabeleceu-se o depósito da quantia na Coletoria das Rendas Gerais em nome do senhor José Francisco de Mendonça em 23 de março de 1887, tendo, no mesmo dia, o juiz de direito Antônio José da Costa Pereira passado a carta de alforria.

Ao determinar os valores máximos que os escravos poderiam alcançar, o Estado pretendia pôr fim aos conflitos judiciais em torno dos preços. Além disso, pelo artigo $3^{\circ}$, parágrafo $9^{\circ}$, a Lei n 3.279 passou a permitir a liberalidade direta de terceiro para a alforria do escravo. A Lei do Ventre Livre não era clara em relação a essa possibilidade, mas permitia que o escravo formasse pecúlio com doações. A proibição só foi explicitada no Regulamento de 1872, numa tentativa de preservar os senhores da intervenção de seus inimigos, ou ainda de pessoas diretamente interessadas na alforria de um escravo.

82 Joseli Maria Nunes Mendonça, Entre a mão e os anéis: a lei dos sexagenários e os caminhos da abolição no Brasil, Campinas: Editora da Unicamp, 1999. 
De acordo com o Regulamento [de 1872], a liberalidade direta de terceiros seria permitida no caso das vendas judiciais ou nos inventários - ocasiões em que os escravos estariam sem senhor, não podendo, neste caso, ser considerada uma afronta ao poder senhorial. Entretanto a lei era ambígua, pois ao mesmo tempo que proibia a liberalidade direta de terceiros, permitia que fizesse parte do pecúlio dos escravos o que ele tivesse adquirido por meio de doações, sendo bastante comum a ajuda de familiares e padrinhos na compra da alforria. Portanto, cabia ao juiz interpretar a ajuda pecuniária como doação ou como liberalidade de terceiro. A Lei dos Sexagenários punha fim a esse conflito. ${ }^{83}$

O processo de liberdade não dá detalhes sobre a forma como Jeremias Damasceno acumulou a quantia de Rs 600\$000, embora se saiba que o padre Antônio Cardoso Damasceno ajudou o libertando nessa conquista. Conforme já salientado, era comum que interessados na mão de obra de homens e mulheres cativos ajudassem-nos na compra da própria alforria. Muitas vezes, com esse ato, o liberto passava à dependência, provocada pela gratidão ao seu benfeitor. Embora o processo não exponha a relação existente entre o padre e o libertando, o fato de Jeremias usar o sobrenome Damasceno sugere uma proximidade entre eles.

Raimunda, de 20 anos, também conseguiu a carta de alforria após o trâmite de uma ação judicial no ano de 1883, sob a alegação de que possuía o equivalente a seu valor e que estava disposta a indenizar a herdeira dona Eulina de Oliveira Guimarães, filha do falecido Sebastião Guimarães, seu antigo senhor, na justa quantia de Rs 700\$000, conforme descrito no inventário do seu pai. A carta foi outorgada após a sentença proferida pelo juiz substituto, coronel João Paulo de Faria, que

[...] fez saber a todas as autoridades a quem o conhecimento desta pertence que a escrava Raimunda de 20 anos de idade mais ou menos parda, natural desta cidade de Mariana, filha de Lizarda, como profissão cozinheira, pertencente ao espólio do finado Sebastião Martins Guimarães, matriculada nesta cidade em data de 23 de setembro de 1872 sob o número 5.201 e na relação 3 tendo apresentado neste Juízo a quantia de setecentos mil réis que obteve generosamente da Sociedade Libertadora

83 Sharyse Piroupo do Amaral, "Escravidão, liberdade e resistência em Sergipe - Cotinguiba, 18601888" (Tese de Doutorado, Universidade Federal da Bahia, 2007), p.206. 
Mineira fundada na cidade de Ouro Preto cuja quantia fica neste Juízo para ser entregue a inventariante D. Eulina de Oliveira Guimarães pelo preço da sua avaliação por isso lhe concedo plena e irrevogável liberdade para que possa conduzir-se de ora em diante como pessoa livre. ${ }^{84}$

O caso de Raimunda parece entrar na exceção do Regulamento de 1872 que permitia a liberalidade direta de terceiros na formação de pecúlio pelos escravos quando das vendas judiciais ou nos inventários. A escrava foi beneficiada pela Sociedade Libertadora Mineira,${ }^{85}$ fundada na capital mineira em 1883, mesmo ano do registro de sua alforria:

A comissão da Sociedade Libertadora Mineira, abaixo assinada, vem apresentar ao juiz a quantia de Rs $700 \$ 000$, por que foi avaliada a escrava Raimunda, no inventário do finado Sebastião Martins Guimarães e requer que junte esta aos autos e se espera a competente carta de liberdade. ${ }^{86}$

Nos anos 1880, na cidade de Ouro Preto-MG, havia outras três sociedades abolicionistas. Eram elas: a Sociedade Abolicionista Ouro-Pretana, o Clube Abolicionista Mineiro Visconde do Rio Branco e o Clube de Libertos Viscondessa do Rio Novo. Luiz Gustavo dos Santos Cota, em estudo sobre as associações abolicionistas de Mariana e Ouro Preto, não precisa quantos escravos foram libertados por meio de suas atividades, nem como angariavam fundos para as alforrias, mas ressalta sua importante atuação na divulgação das ideias abolicionistas, inclusive pela imprensa escrita. ${ }^{87}$

${ }^{84}$ Carta de Alforria (02/11/1883), Arquivo da Casa Setecentista de Mariana (ACSM), Carta de alforria, I ofício, livro 123 (1881-1887), folha 58.

85 Acerca dessas associações, ver Luis Gustavo Cota, "O Abolicionismo das Minas: um breve estudo comparado do movimento abolicionista nas Cidades de Ouro Preto e Juiz de Fora nos últimos anos da escravidão", in Eduardo Paiva (org.), Escravidão, mestiçagem e histórias comparadas (São Paulo: Annablume, 2008).

86 Inventário post-mortem de Sebastião Martins Guimarães (1883), Arquivo da Casa Setecentista de Mariana (ACSM), Inventário, II ofício, códice 103, auto 2159, folha 260.

87 Luis Gustavo Cota, "O sagrado direito da liberdade: emancipacionismo e abolicionismo em Ouro Preto e Mariana (Minas Gerais, 1871-1888)", Anais do $1^{\circ}$ Colóquio do Laboratório de História Econômica e Social, Juiz de Fora, 2005. Em Mariana, as associações emancipacionistas estavam ligadas às irmandades. Em 1855, foi criada a Associação Marianense Redentora dos Cativos, vinculada à Confraria de Nossa Senhora das Mercês, que tinha como principal objetivo libertar os escravos nela alistados (Cota, "O sagrado direito da liberdade"). No ano de 1881, a menina Catarina, escrava de dona Maria Francisca do Carmo, foi alforriada depois de as irmãs do Colégio da Providência recolherem esmolas de diversas pessoas da comunidade. A Irmã Superiora conseguiu arrecadar R $\$ 800 \$ 000$, valor arbitrado pela coletoria, conforme determinava a lei de 1871 para os casos de alforria concedida por intermédio do Estado. O referido processo de liberdade encontra-se no Arquivo da Casa Setecentista de Mariana (ACSM), I ofício, códice 316, auto, 7557. 
A libertação de Rosa africana também foi resultado de uma doação que necessitou da interferência da Justiça para que obtivesse êxito. A lavratura da alforria foi feita em 1877 — o mesmo ano da abertura do inventário do tenente-coronel José Custódio Pereira Brandão, antigo proprietário de Rosa - e o benfeitor da escrava foi seu próprio filho, Augusto Pedro Nolasco, que também havia sido cativo do tenente. De acordo com o documento exarado pelo Doutor Carlos José Augusto de Oliveira, juiz municipal e de órfãos na cidade de Mariana e seu termo,

[...] aos que a presente carta virem faço saber que procedendo-se ao inventário dos bens do tenente coronel José Custódio Pereira Brandão foi avaliada a escrava Rosa matriculada com o número 127 da matrícula geral e número 16 da relação em 300 mil réis e por parte de Augusto Pedro Nolasco, filho da mesma e legatário do dito tenente coronel Brandão foi cedida a referida quantia nas forças do legado para liberdade de sua mãe e em virtude do artigo 90 parágrafo um, artigo segundo do decreto número 5135 de 13 de novembro de 1872 mandei passar a presente carta pela qual declaro liberta a referida escrava Rosa e portanto de hoje em diante no gozo dos direitos civis. ${ }^{88}$

De acordo com o inventário do falecido tenente-coronel, em 1877, Rosa africana era mineira de profissão, tinha 50 anos, estava doente, havia sido avaliada em Rs $300 \$ 000$ e era mãe de Augusto e Paulino. No mesmo inventário, Augusto foi descrito como pardo, com 29 anos, caseiro, avaliado em Rs 150\$000, e Paulino, com 27 anos, caseiro, foi avaliado em Rs 1:500\$000. Conforme a carta de alforria de Rosa, Augusto era legatário do militar, que, em seu testamento, transcrito no inventário, havia declarado que era de sua vontade que, um ano após seu falecimento, o escravo $\mathrm{Au}-$ gusto Pedro Nolasco ficasse liberto, ocasião em que receberia a quantia de Rs 1:000\$000, correspondente ao valor dos jornais pelos serviços prestados naquele ano. Augusto conseguiu legitimar em juízo a doação da quantia necessária à alforria de sua mãe, possibilitando-lhe receber sua carta de liberdade. Também nesse caso, a doação com a finalidade de alforriar Rosa só foi possível porque o tenente-coronel já havia falecido. Augusto recorreu à Justiça com a justificativa transcrita a seguir:

${ }_{88}$ Carta de alforria (06/08/1877), Arquivo da Casa Setecentista de Mariana (ACSM), II ofício, livro 21 (1876-1878), folha 35. 
Augusto Pedro Nolasco, escravo que foi do Tenente Coronel José Custódio Pereira Brandão, tendo de haver do espólio deste o legado de um conto de réis como consta de seu testamento, junto por cópia aos autos do inventário, desejoso e resolvido a alforriar sua mãe Rosa, que foi descrita e avaliada no mesmo inventário na quantia de Rs 300\$000, usando da faculdade que lhe concede o Decreto número 5.135 de 13 de novembro de 1872 , artigo 90 parágrafo $2^{\circ}$, oferece a dita quantia de $300 \$ 000$ para libertação de sua mãe. Sendo maior o suplicante e estando no gozo de seus direitos civis e políticos, requer, que se junte esta e a certidão de idade que oferece, aos autos do inventário, e ali se tome o termo de avaliação da quantia de Rs $300 \$ 000$ que o suplicante possui para liberdade de sua mãe Rosa, depois do que se declara liberta a mesma na forma da Lei citada. ${ }^{89}$

A escrava Raimunda Madalena Augusta foi beneficiada pelo Fundo de Emancipação no ano de 1884. Solteira e sem filhos, não estava, de acordo com os critérios de classificação, entre os escravos com prioridade para serem libertados pelo fundo, porém uma questão distinguia-a dos demais: a existência de um pecúlio. Segundo sua senhora, dona Francisca Herculana de Assis, "pelo amor que tenho por tê-la criado permiti que a mesma fosse trabalhando cedendo-lhe eu a metade dos jornais para serem aplicados a sua liberdade". ${ }^{90}$ Continuando, dona Francisca afirmou que

[...] tendo ao presente recebido por diversas vezes da referida Raimunda a quantia de 672 mil réis importância esta da metade dos jornais que cedi em benefício de sua liberdade e de doações que me fizeram resolvi dar a mesma em benefício de sua liberdade mais a quantia de 128 mil réis ficando o restante na quantia de 100 mil réis do que me passou nesta data crédito cujas quantias unidas perfazem o de 900 mil réis por que lhe concedo liberdade da qual gozará de ora em diante. ${ }^{91}$

Analisando as alforrias concedidas pelo Fundo de Emancipação na Corte, Lucimar Felisberto dos Santos constatou que os escravos

89 Inventário post-mortem do Tenente Coronel José Custódio Pereira Brandão (1977), Arquivo da Casa Setecentista de Mariana, Inventário, I ofício, códice 99, auto 2073, folha 41.

90 Carta de Alforria (10/11/1884), Arquivo da Casa Setecentista de Mariana (ACSM), I ofício, livro 123 (1881-1887), folha 73v.

91 Carta de Alforria (10/11/1884), Arquivo da Casa Setecentista de Mariana (ACSM), I ofício, livro 123 (1881-1887), folha 73v. 
solteiros que possuíssem pecúlio sairiam na frente na classificação das categorias individuais. A autora encontrou vários casos de escravos que encaminharam à Junta de Classificação requerimentos declarando serem possuidores de pecúlio. ${ }^{92}$ No caso da escrava Raimunda, o fundo apenas complementou a quantia necessária para sua alforria, que foi acordada sem a necessidade de um processo, pois sua senhora concordou com a indenização no valor de Rs $900 \$ 000$.

Também Ildefonso foi agraciado com a carta de alforria por meio do Fundo de Emancipação no ano de 1885, possivelmente antes da vigência da lei de 1885, pois seu valor foi superior ao fixado pela tabela do documento legal - o preço estabelecido pela legislação para homens com idade entre 30 e 40 anos era de Rs $800 \$ 000$. Diz sua carta que

[...] o escravo Ildefonso, de cor parda, de 40 anos, casado, carpinteiro, matriculado com o número 6.904 da matrícula geral e pertencente a Cristovão Alves da Costa foi declarado livre por este juízo pela sexta cota do Fundo de Emancipação distribuída neste município pela quantia de 850 mil réis por ter este o preço feito por seu senhor e ao coletor municipal. Portanto, concedo-lhe plena e irrevogável liberdade para que possa d'ora em diante conduzir-se como pessoa livre em virtude da lei de 28 de setembro de $1871 .^{93}$

João, feito forro pelo Fundo de Emancipação em 1887, teve seu valor aquém do estabelecido pela lei de 1885. Produzida pelo tenentecoronel Eleutério de Souza Novaes, terceiro suplente do juiz municipal e de órfãos, sua carta de alforria informa:

[...] faço saber aos que a presente carta de liberdade virem que em virtude do artigo 42 do regulamento a que se refere o Decreto número 1.185 de 13 de novembro de 1872 em audiência pública deste juízo no dia 27 de fevereiro do corrente ano foi declarado liberto pela sétima cota do Fundo de Emancipação o escravo João de cor preta de 33 anos pertencente a

92 Lucimar Felisberto dos Santos, "Os bastidores da lei: estratégias escravas e o Fundo de Emancipação", Revista de História. v.1, n.2 (2009), pp.18-39. Entretanto, segundo a autora, “os números do relatório enviado ao Ministério da Agricultura sugerem claramente que os valores do pecúlio dos cativos, que efetivamente foram libertos, não tiveram peso significativo no montante das indenizações" (Santos, "Os bastidores da lei", p.33).

93 Carta de Alforria (20/09/1885), Arquivo da Casa Setecentista de Mariana (ACSM), II Ofício, livro 25 (1884-1885). 
Inácio José Paes casado com o número da antiga matrícula 115, pela quantia de 700 mil réis em que concordaram as partes. ${ }^{94}$

Outros dois escravos libertados após a lei de 1885 também tiveram relacionados na carta valor inferior ao determinado pela lei. Lourença, de cor preta, 36 anos, casada, foi manumitida pelo Fundo de Emancipação no ano de 1887 depois de indenizar sua senhora, dona Ana Leopoldina de Oliveira, no valor de Rs 500\$000, "em que concordam as partes". 95 Pela lei, o valor de uma escrava com a idade de Lourença correspondia a Rs 600\$000 (Tabela 6). Ildenso, casado, de 24 anos, foi declarado liberto pela sétima cota do Fundo de Emancipação, e seu senhor, o alferes Justiniano Moreira Ramos, indenizado pela quantia de 700 mil réis. ${ }^{96}$ Pela dita lei, o valor de Ildenso corresponderia a Rs $800 \$ 000$ (Tabela 6).

Antes da lei de 1885, que determinava o preço máximo dos escravos, as partes - Estado e proprietário — deveriam estar em concordância com o valor da indenização, o que nem sempre acontecia. O processo de libertação dos escravos via Fundo de Emancipação tinha seus trâmites: a Junta Classificadora elaborava a lista dos escravos a serem beneficiados pelo governo, num determinado ano, de acordo com os critérios estabelecidos pelo Regulamento $\mathrm{n}^{\mathrm{0}} 5.135$, de 13 de novembro de 1872, e pelo Aviso de 8 de junho de 1876; tal lista, que continha as características dos escravos beneficiados e os valores das indenizações, era editada e publicada para que os proprietários dos listados pudessem manifestar-se acerca dos valores arbitrados; sendo os valores de indenização questionados, cabia à junta realizar novo arbitramento; caso não houvesse questionamento, a Junta de Emancipação comunicava aos respectivos senhores que comparecessem no dia e hora designados para que, em audiência pública, fossem entregues as cartas de alforria.

Foram localizadas duas listas — referentes aos anos de 1882 e 1883 - de classificação de escravos que seriam libertados pelo Fundo de

94 Carta de Alforria (27/02/1887), Arquivo da CSM, Carta de alforria, II ofício, livro 28 (18861887), folhas 16 e $16 \mathrm{v}$.

95 Carta de Alforria (27/02/1887), Arquivo da CSM, Carta de alforria, II ofício, livro 28 (18861887), folhas $16 \mathrm{v}$ e 17.

96 Carta de Alforria (27/02/1887), Arquivo da Casa Setecentista de Mariana (ACSM), II ofício, livro 28 (1886-1887), folhas $19 \mathrm{v}$. 
Emancipação. ${ }^{97}$ A primeira trazia sete escravos: ${ }^{98}$ Jacinto, 12 anos de idade, filho do casal Joaquim e Antônia (já libertos pelo Fundo de Emancipação), no valor de Rs $850 \$ 000$, pertencente aos herdeiros de dona Maria Fausta Guimarães; João, casado com mulher livre, no valor de Rs 1.300\$000, pertencente a dona Maria Magdalena de Castro; Jacinto, casado com mulher livre, no valor de Rs 500\$000, pertencente a Antônio Duarte Pinto; Adão, casado com mulher livre, no valor de Rs $1.400 \$ 000$, pertencente a Antônio Moreira da Cruz; Mariano, 35 anos, casado com mulher livre, no valor de Rs 1.600\$000, pertencente ao doutor Theophilo Pereira da Silva; Inácio, casado com mulher livre, no valor de Rs $1.600 \$ 000$, pertencente a Martinho Freire de Andrade; Jacinta, casada com homem livre, no valor de Rs 800\$000, pertencente a Manuel Pedro Cotta Sobrinho.

Dos sete proprietários dessa quota, seis contestaram o valor arbitrado pelo Fundo de Emancipação. Dona Maria Magdalena de Castro, proprietária do escravo João, estimou seu valor em Rs $1.600 \$ 000$, ou seja, Rs $300 \$ 000$ a mais que o ajuizado. Antônio Duarte Pinto teve determinado o valor de Rs 500\$000 para seu escravo Jacinto e procurou a coletoria a fim de manifestar seu descontentamento e requerer uma indenização de Rs 800\$000. O doutor Theophilo Pereira da Silva também respondeu ao edital manifestandose insatisfeito com a avaliação realizada pelo Fundo de Emancipação que estimou Mariano em Rs 1.600\$000: "em vista do estado robusto do escravo, sua idade, boa saúde, profissão de bom arrieiro, sem vício, quer físico, quer moral exige pelo mesmo a quantia de Rs 2.000\$000". ${ }^{99}$ Martinho Freire de Andrade, que teve seu escravo Inácio apreciado em Rs 1.600\$000, respondeu ao edital requerendo que o mesmo fosse avaliado em Rs $2.000 \$ 000$.

97 Ambas as listas faziam parte de conjuntos mais amplos de documentos que incluíam editais de publicidade, acordos judiciais, sentenças e cartas de alforria, dispersos no Arquivo Histórico da Câmara Municipal de Mariana, garimpados e reconstituídos para a presente pesquisa. Quase toda a documentação relativa a cada lista foi encontrada, exceto as cartas de alforria, o que não impediu que fossem conhecidos os destinos de cada escravo, pois foram descritos nos acordos e sentenças; contudo, esses casos não puderam ser computados na análise quantitativa aqui apresentada.

98 Arquivo Histórico da Câmara Municipal de Mariana, Fundo de Emancipação, documento 27. A lista para o ano de 1883 trazia 18 escravos que deveriam ser libertados naquele ano. O número de escravos libertados por cada município por intermédio do fundo era determinado pela quantia destinada às Coletorias de Rendas Municipais. Em 1882, Mariana recebeu a quantia de Rs. $8.069 \$ 020$ para ser aplicada na alforria dos escravos que viviam em suas propriedades. Já no ano de 1883, o valor recebido do Fundo de Emancipação foi de Rs. $13.000 \$ 000$ (Arquivo Histórico da Câmara Municipal de Mariana, Fundo de Emancipação, documento 15).

99 Arquivo Histórico da Câmara Municipal de Mariana, Fundo de Emancipação, documento 6. 
Jacinta, pertencente a Manuel Pedro Cotta Sobrinho, foi apreçada em Rs $800 \$ 000$ pela Junta de Classificação, entretanto, seu proprietário contestou esse valor, requerendo o correspondente a Rs $1.600 \$ 000$.

A Junta de Classificação desconsiderou todos os requerimentos pedindo alteração do valor da indenização pelos escravos alforriados, conforme os "termos ordenados na lei e quando não haja acordo seja o suplicado intimado para proceder-se $o$ arbitramento na primeira audiência deste Juízo, tudo na forma da lei". ${ }^{100}$ Concluída essa etapa, no dia 22 de outubro de 1882, os sete escravos receberam a carta de alforria das mãos de seus antigos proprietários.

Exemplifique-se com o acordo estabelecido entre o fundo e o senhor Martinho Freire de Andrade com o seguinte teor:

Aos 19 dias do mês de setembro do ano de 1882, nesta cidade de Mariana em meu cartório compareceu o cidadão Martinho Freire de Andrade ao capitão Torquato José de Oliveira Moraes, agente do coletor das rendas gerais deste município. Pelo dito cidadão Martinho Freire que apresentado para ser libertado pelo fundo da emancipação, seu escravo Inácio, exigiu pelo mesmo a quantia de Rs 2.000\$000 como indenização, mas havendo a junta considerado a indenização do mesmo em Rs $1.600 \$ 000$ caberá essa quantia a ser fornecida em benefício da liberdade do dito escravo. ${ }^{101}$

Os artigos que compunham a lei de 1871 ampliaram os horizontes da liberdade independentemente da vontade do senhor. O reconhecimento do direito ao pecúlio - que poderia ser advindo de heranças e doações ou como fruto do próprio trabalho - para ser utilizado na compra da própria alforria foi um dos ganhos que o escravo obteve com essa legislação. Se era necessária ao escravo a autorização senhorial para trabalhar e acumular ganhos para si próprio, ficava ele liberado de pedir permissão para compra da sua própria alforria, caso provasse ter meios para indenizar o senhor no correspondente ao seu valor. O pecúlio passou, assim, a ser regulamentado, dando amparo legal a essa prática, podendo o cativo defender esse direito em juízo. Se o proprietário não concordasse com a quantia oferecida por seu escravo, ela seria arbitrada pelo Estado.

\footnotetext{
${ }^{100}$ Arquivo Histórico da Câmara Municipal de Mariana, Fundo de Emancipação, documento 12.

${ }^{101}$ Arquivo da CSM. Acordo para emancipação do escravo Inácio. I Ofício, Códice 299, auto 6672.
} 
Além disso, também ficou estabelecido que o Fundo de Emancipação ajudaria a promover a libertação gradual dos escravos no Império. Para que essa tarefa fosse possível, a própria lei ordenou a realização de uma matrícula geral dos mancípios em todo o país e a posterior classificação dos cativos por juntas especiais constituídas para esse fim em cada município. Após a matrícula e a classificação, os recursos arrecadados pelo fundo seriam repartidos entre os municípios de cada província, proporcionalmente ao seu número de escravos, e destinados à indenização dos senhores pelos escravos a serem libertados. Segundo a lei, os escravos não matriculados estavam automaticamente livres. Estavam igualmente livres os escravos vítimas de violência e abandono. E, após 1885, também os escravos com mais de 65 anos. A Lei Saraiva-Cotegipe determinou também os preços máximos que os escravos poderiam alcançar e passou a permitir a liberalidade direta de terceiro para a alforria do escravo. Nos casos de alforrias conquistadas por meio do pecúlio, parece que o princípio da liberalidade atuou entre os escravos de Mariana. Em todos os casos de alforria concedida ao escravo por meio do pecúlio, a quantia necessária à compra da liberdade foi obtida por meio de doações.

A partir de então, o Estado passou a atuar no que era considerado propriedade privada, interferindo diretamente na relação senhor/escravo. Uma vez considerando-se viver em injusto cativeiro ou possuindo pecúlio correspondente ao seu valor, o cativo podia vislumbrar a liberdade, mesmo à revelia de seu senhor, percorrendo, porém, o caminho judicial para a obtenção da alforria pelas ações de liberdade, que, após 1871, cresceram em número. Pelas cartas de alforria resultantes das ações de liberdade, os cativos, beneficiados pela legislação abolicionista e apoiados por curadores e advogados, agiram em favor da própria liberdade e da de seus familiares.

Ao todo, foram encontradas 27 cartas de alforria que libertavam mancípios com o auxílio do Estado, com base na gradual ingerência da legislação abolicionista. Contudo, o número de alforriados por esse caminho foi certamente mais alto, como demonstram as listas de classificação acima mencionadas. 


\section{Considerações finais}

Em Mariana, confirmou-se o que outras pesquisas já haviam demonstrado para outras localidades: a preponderância das alforrias condicionais; elas somam mais que o dobro das incondicionais. As concedidas pelo Estado, principalmente com base nas leis vigentes a partir de 1871, tiveram pequena participação numérica, mas foram bastante emblemáticas, pois materializaram a ingerência do poder público nas relações privadas de propriedade entre senhores e seus cativos.

Através do tempo, as cartas que exigiam prestação de serviços ou pagamento em dinheiro foram perdendo representatividade para as que não demandavam ônus algum, até que, na década de 1880, ambas detiveram a mesma expressão. As cartas lavradas por força de ação do Estado surgiram após a lei de 1871 e cresceram significativamente de uma década para outra (dos anos 1870 aos 1880).

Entre as alforrias que demandavam algum encargo para a emancipação, predominavam as que os libertandos prestariam serviços, normalmente até o fim da vida do senhor. Pelo menos $85 \%$ dos que deviam prestação de serviços permaneciam na propriedade de origem até a morte do senhor e, mesmo depois disso, em alguns casos, a situação mantinha-se inalterada até a morte de cônjuge e/ou filhos. Nesses termos, a carta de alforria não rompia, portanto, com o sistema de trabalho obrigatório.

Quase um quinto dos escravos alforriados teve de pagar uma soma em dinheiro pela própria alforria, geralmente em prestações e, enquanto não atingisse o valor combinado, não se afastaria da propriedade em que vivia. Houve, com alguma regularidade, casos em que o pecúlio necessário ao pagamento da alforria foi fornecido por terceiros, quando a subordinação dos libertos apenas mudava de mãos até que os serviços prestados quitassem a dívida. Mais uma vez, a alforria não se traduzia em liberdade imediata. Havia ainda ocasiões em que um familiar pagava pela liberdade do cativo.

Com justificativas do tipo "pelo amor que the tenho" ou "pelos bons serviços prestados com lealdade", menos de um terço dos aforrados recebeu sua carta incondicionalmente. Os beneficiados eram, sobretudo, os mais velhos, mas também muitos enfermos. Era ainda comum que as crianças recebessem cartas sem ônus algum, justificadas por afeto 
ou mesmo por parentesco. Parte desses cativos permanecia em situação semelhante àquela de antes da alforria, vivendo em companhia de seus antigos senhores, por não terem para onde ir, pelas relações sociais que construíram ali ou mesmo por gratidão aos antigos senhores. Em algumas situações, não incomuns, os escravos alforriados receberam uma espécie de salário quando mantidos na antiga propriedade.

Os casos de libertação após a interferência do Estado não foram muito significativos em termos estatísticos, mas simbolizaram novas possibilidades de alcançar-se a liberdade, cada vez menos dependente da vontade senhor. $\mathrm{O}$ direito à formação de pecúlio, a desnecessidade de aprovação do senhor para comprar a própria alforria caso tivesse em mãos o pecúlio e a criação do Fundo de Emancipação foram algumas das vantagens conquistadas pelos cativos com a nova legislação. Além disso, escravos não matriculados ganhavam liberdade automaticamente, assim como escravos vítimas de violência e abandono e aqueles com mais de 65 anos de idade.

A conquista de uma carta de alforria muito dificilmente correspondia à liberdade imediata como hoje se tende a supor. As alforrias condicionais, maioria entre as lavradas na Mariana de 1840 a 1888, quase sempre levavam o liberto a mal vislumbrar o horizonte da efetiva libertação. Por meio da prestação de serviços por longos períodos (muitas vezes sem data conhecida, por não se poder prever o dia de morte de proprietários ou de seus filhos) ou pelo pagamento de quantia correspondente a seu valor (sempre alto para as possibilidades de acumulação de um escravo, o que o levava a pagar-se em longas prestações, que deveriam ser quitadas antes de deixar a propriedade onde vivia), o senhor manteria a força de trabalho de um homem grato (principalmente por sua mudança de status de escravo a forro) e esperançoso de um dia ter o poder de decidir seu destino, além de gerar a mesma expectativa de liberdade no restante de sua escravaria. Mesmo as alforrias ditas incondicionais, no mais das vezes, tenderam à permanência, mais do que à mudança. Não raro, os forros depararam-se com uma das três situações que os mantinham no mesmo espaço em que viviam quando eram escravos: não ter para onde ir, gratidão ao senhor que o libertou ou ter ali sedimentadas suas relações sociais ou familiares.

Recebido em julho de 2013 e aprovado em janeiro de 2014. 


\section{Resumo}

Este artigo analisa o padrão das alforrias na localidade mineira de Mariana (economicamente voltada para a subsistência) a partir das cartas de liberdade, durante o período 1840-1888, buscando apreender as transformações na concessão da manumissão no contexto das leis abolicionistas.

Palavras-chave: Escravidão - alforrias - leis abolicionistas - economia de subsistência.

\section{Abstract}

This article intends unveil the manumission pattern in Mariana, at the Minas Gerais province, a subsistence economy based town, by the analysis of letters of enfranchisement through 1840 to 1888 , realizing the transformations on the practices of granting freedom, regarding the abolitionist laws period.

Keywords: Slavery - manumissions - abolitionist laws - subsistence economy. 